\title{
Tegnologiese innovasie en Suid-Afrika
}

Brig F. Shylock Mulder*

The article below deals with technological developments in the Republic of South Africa necessitated by the arms boycotts engineered against the Republic by the United Nations Organisation. The writer of the article stresses the need for co-ordination and sinchronization of research and development in the field of technology in South Africa especially with regard to priorities and effort.

"A new form of Military Technological Strategy - each side is merely trying to outdo in performance the equipment of the other side - its object is to make them functionally obsolete -" André Beaufré

\section{Inleiding}

Die propaganda-aanslag teen die RSA het in die jare 1960 ' $n$ nuwe en verskerpte fase binnegegaan. Aanvanklik was gekonsentreer op politieke argumente waarin die RSA as ' $n$ "kolonialistiese moondheid" voorgehou is ten einde die steun van en simpatie met die Derde Wêreld te demonstreer. In die lig van onder andere Brittanje en Frankryk se verbintenisse in Afrika, op daardie stadium, het die aanslag nie na wense gevorder nie. Daar moes na 'n ander benadering in die propaganda-oorlog gesoek word.

Die verskerpte fase in hierdie aanslag het begin met wapenboikotte wat deur die VN van stapel gestuur is. Die rasionaal hier agter was om die RSA tegnologies te isoleer. Tegnologiese ontwikkeling is naamlik die oorwegende faktor wat bydra tot die ekonomiese groei van ontwikkelende lande soos die RSA. Die volgende groeipunte kom daarvoor in aanmerking:

- Tegnologiese ontwikkeling voorsien ' $n$ toename in werksgeleenthede;

- tegnologiese ontwikkeling dien as aansporing vir verdere navorsing en ontwikkeling;

- verhoogde uitvoere as gevolg van tegnologiese ontwikkeling dra by tot die verhoging van die betalingsbalans.

Aan die ander kant moet egter in aanmerking geneem word dat hierdie "hoë tegnologie" in 'n land soos Suid-Afrika ' $n$ massiewe uitleg verg in terme van die voorsiening van infrastrukture op grond waarvan die ontwikkeling moet plaasvind. Ons dink hier aan opvoeding, navorsing en bestuursopleiding.

Dit is egter ' $n$ historiese waarneming dat die mees gevorderde tegnologie van die tyd altyd eerste in die veld van krygstuig toegepas word en dit is vandag meer waar as ooit. Toerusting is kompleks en gesofistikeerd en waar dit dan ook aan die hoogste vereistes van betroubaarheid moet beantwoord, is die vervaardiging daarvan gevolglik moeilik te bemeester en die produk duur. Hierteenoor het die ontwikkeling van 'n plaaslike krygstuignywerheid reeds groot bedrae aan buitelandse valuta bespaar.

Goed ontwikkelde tegnologiese vermoë bied buigsaamheid in produkstrategie, maar hoë tegnologie produkte is per eenheid duurder en vereis ' $n$ groter mark. Die ekonomiese gelykbreekpunt vereis groter produksie-hoeveelhede.

\section{Tegnologie:}

Benadering. Die belangrikheid van tegnologiese ontwikkeling vir die RSA kan nie maklik oorbeklemtoon word nie. Elkeen van ons het daagliks te doen met die produk van tegnologiese ontwikkeling in die vorm van vervoermiddels wat ons gebruik, ons horlosies, ons sakrekenaars en vele ander fasette van ons lewe. As tegnologie van nader beskou word, kan dit ten beste beskryf word as die wyse waarop menslike aktiwiteite verrig word. Alhoewel tegnologie tussen die natuurwetenskappe en geesteswetenskappe aan die een kant, en die ekonomiese toepassings aan die ander kant, staan, moet dit as ' $n$ afsonderlike begrip binne die "tegnologiese innovasie" konteks bestudeer word. Selfs in die huidige ekonomiese klimaat, waar die aandag op kostebesparing en produktiwiteitsverhoging toegespits word, mag die belangrikheid van tegnologiese ontwikkeling en -innovasie nie uit die oog verloor word nie, trouens, tegnologieontwikkeling moet reeds gemik word op produktiwiteitsverhoging.

Die Aard van Tegnologie. Elke menslike aktiwiteit, gesien uit 'n oorkoepelende gesigspunt, bestaan uit ' $n$ verskeidenheid van insette (soos grondstowwe, mannekrag, energie, fasiliteite, fondse, inligting ens.) wat deur ' $n$ omsettingsak- 
sie omvorm word tot een of meer uitsette (beide gewens - soos produkte, dienste, inligting en neweprodukte - en minder gewens - soos afval en besoedelingstowwe) in ' $n$ bepaalde omgewing (fisies, ekologies, sosiaal ekonomies, polities, infrastruktuur ens.).

Tegnologie. Aangesien tegnologie die wyse is waarop 'n aktiwiteit verrig word, is dit duidelik dat, hoewel tegnologie hoofsaaklik die aard van die omsettingsaksie bepaal, elke unieke vloeimengsel 'n karakteristieke tegnologie vereis. Indien een of meer van die komponente van die vloeimengsel dus verander, moet daar in meeste gevalle ' $n$ ander tegnologie daaraan gekoppel word. Die omgekeerde is egter ook waar dat veranderings in ' $n$ tegnologie, teweeggebring byvoorbeeld deur nuwe wetenskaplike kennis, heel dikwels aanleiding gee tot onvermydelike veranderings in die vloeimengsel. Die beskrywing van ' $n$ tegnologie moet dus aandui met watter vloeimengsel die betrokke tegnologie gekoppel is. Soos Leontief (1982) dit stel: "Technological change can be visualized conveniently as change in the cooking recipes ... followed by different industries to produce their respective outputs". Hierdie opvatting oor tegnologie is egter hoofsaaklik van toepassing op proses-tipe, of industriële tegnologie. Die innovatiewe (N\&O) tipe tegnologie is veel meer kompleks, terwyl stelsel-tegnologie boonop meer dissiplinêr is.

Innovasie. Innovasie of vernuwing beteken die bekendstelling en voorstelling van iets nuuts, om iets nuuts te skep, iets wat afwyk van die bestaande gebruike. Die Collins English Dictionary (1980: 754) beskryf innovasie as volg: "to invent or begin to apply new methods, ideas. Innovation: something newly introduced such as a new method or device". Innovasie is 'n verbetering wat meetbaar, doelbewus, standhoudend is en onwaarskynlik dikwels sal voorkom. Innovasie behoort egter doelbewus en bepland bestuur te word en is die proses waardeur tegnologie ontwikkel word.

Die Tegnologiese Innovasieproses. Tegnologie-ontwikkeling volg twee verskillende paaie $\mathrm{nl}$, markgedrewe innovasie en tegnologie-gedrewe innovasie. Die tegnologiese innovasieproses beskryf markgedrewe innovasie. Alhoewel die indruk geskep mag word dat tegnologie sonder moeite ontwikkel en toegepas word, vind sodanige ontwikkeling en inwerkingstelling van tegnologie plaas deur die sogenaamde innovasieproses waaraan doelbewuste aandag gegee moet word. Hierdie proses bestaan uit die volgende stappe (Hofmeyr, 1982):

- die bepaling van die funksionele behoefte waaraan die tegnologie moet voldoen, wat veral op die markbehoefte berus;

- die versameling van alle beskikbare tegnologiese kundigheid en wetenskaplike kennis wat moontlik van nut kan wees;

- die evaluasie van die geskiktheid van die beskikbare tegnologie om die ekonomiese en tegniese lewensvatbaarheid daarvan in die huidige of verlangde vloeimengsel aan te dui en om alle moontlike direkte en indirekte voordele en nadele daarvan uit te wys;

- die ontwikkeling, indien die beskikbare tegnologie nie aan al die belangrikste vereistes voldoen nie, van aangepaste of verbeterde tegnologie deur navorsing en ontwikkeling. Hierdie stap moet gevolg word deur ' $n$ verdere evaluasie van die aangepaste of verbeterde tegnologie;

- die oordrag van die tegnologie na moontlike gebruikers; en

- die inwerkingstelling van die tegnologie, wat vereis dat aandag gegee word aan aspekte soos finansiering, produksiestelsels, fasiliteitskepping, skepping van tegnologiese infrastruktuur, bemarking en alle ander bedryfsekonomiese aspekte.

Stappe. Aangesien die innovasieproses uit 'n reeks opeenvolgende stappe bestaan, kan die tegnologie slegs effektief benut word as behoorlike aandag aan elke van hierdie stappe gegee word. Veral die navorsing en ontwikkeling (N\&O) en inwerkingstellingstappe verg gewoonlik ' $n$ aansienlike belegging van fondse en tyd. Beide hierdie stappe is dan ook verantwoordelik vir die hoë risiko-element wat tegnologiese innovasie kenmerk. Die risiko kan egter gedeeltelik uitgeskakel word as die ander stappe in die proses voldoende aandag kry. Dit is in hierdie verband dat die bedryfsekonomie ' $n$ baie belangrike bydrae kan lewer.

\section{Die RSA se tegnologie situasie}

\section{Beperkings:}

Hulpbronne. Die teenwoordigheid of afwesigheid van ' $n$ tegnologiese infrastruktuur kan op sigself ' $n$ kragtige invloed op die invoer van nuwighede wees. As die skepper van 'n nuwe teg- 
nologie die hulpbronne wat hy nodig het maklik kan bekom, kan hy vinnig in die veld in beweeg. As hy egter hierdie vaardighede eers moet skep of van afgeleë bronne moet verkry, sal die vorderingstempo vertraag word.

Navorsing. Hierdie oorwegings wys na die rol van navorsing en ontwikkeling, $\mathrm{nl}$ om te fungeer as ' $n$ skakel in ' $n$ ketting van verandering. Dit het op sy eie geen identiteit nie, maar slegs ' $n$ funksie om uit te voer waardeur die vloei van verandering meer doeltreffend plaasvind. Die vereistes van navorsing ten opsigte van die skepping van ' $n$ infrastruktuur en van navorsingsmetodologie asook die implikasie van hierdie vereistes, word erken (Maddock, 1981). Die ideale toestand is om te streef na 'n gepaste balans tussen basiese en toegepaste navorsing en ontwikkeling. Om ons wetenskaplik-tegnologiese bekwaamhede uit te brei, is daar verdere aspekte wat voorrang-aandag moet geniet.

Beperkte Mannekrag. Een van die grootste beperkings wat Suid-Afrika se tegnologie beïnvloed, is die beperkte hoeveelheid gevorderde mannekrag soos bv. wetenskaplike-, tegnieseen bestuursmannekrag, wat vir al die stadiums van die gebruiksproses beskikbaar is. Om die nasionale navorsing en ontwikkelingskema op ' $n$ gesonde voet te plaas, moet die opleiding en voorsiening van die benodigde personeel só beplan word om in die behoeftes van die land te voorsien wat betref verskeidenheid, getalle en kwaliteit. Die mikpunt moet dus wees om 'n balans tussen die aanvraag vir mannekrag en mannekragvoorsiening te verkry. Hierdie balans moet nagestreef word deur:

- 'n ondersteunende onderwysprogram;

- effektiewe beroepsleiding;

- stimulering, uitbreiding en bevordering van navorsing en universiteite soos vereis; en

- die aanwending van ' $n$ wetenskaplik gebaseerde salarisstruktuur om meer aantreklike loopbaanvooruitsigte aan wetenskaplikes te bied.

- Waar ons mank gaan aan getalle kundig mense, moet meer aandag gegee word aan die effektiewe benutting daarvan.

- Goeie en doelgeskikte opleiding met langtermyn loopbaan-geleenthede om kontinuitteit in kundigheid te verseker.

Navorsers. Daar is tans ongeveer 11150 navorsers, 5600 tegnici en 6500 ander ondersteunende personeel, wat jaarliks ongeveer 15000 man-jare aan navorsing spandeer. Van die na- vorsers is $23 \%$ in die staatsektor, $57 \%$ in tersiêre opvoeding, $19 \%$ in die besigheidsektor en $1 \%$ in die nie-winsgewende sektor werksaam. Die aantal man-jare wat navorsers vir elke 10000 van die bevolking aan navorsing en ontwikkeling spandeer, is volgens internasionale standaarde laag. Dit beloop 2,4 vir die bevolking in vergelyking met 10,2 in Israel, 35,6 in Japan, 13,8 in Brittanje en 19,5 in Australië (Science Policy and Development Programme for the RSA, 1982).

Aanvraag en Aanbod. Die bogenoemde oorwegings dui duidelik die behoefte vir ' $n$ meer gekonsentreerde en intensiewe poging aan om personeel in die hoër vaardighede op te voed en op te lei, om sodoende die noodsaaklike balans tussen aanvraag en aanbod van toepaslik gekwalifiseerde personeel vir alle stadiums van die proses van die invoer van nuwighede te verkry.

Ingevoerde Tegnologie. Suid-Afrika is tot ' $n$ hoë mate afhanklik van ingevoerde tegnologie. Die private sektor moet meer by navorsing en ontwikkeling betrokke raak, terwyl navorsers hulle meer op die behoeftes van die mark moet toespits. Op hierdie stadium word die meeste navorsing en ontwikkeling vir die private sektor oorsee gedoen en dan in ons ekonomie ingevoer. Die manier waarop ons tegnologie probeer invoer is nie altyd effektief nie (verwys na lisensie-ooreenkomste). Daar is in Suid-Afrika ' $n$ behoefte aan ondersteuning in die transformasie van tegnologiese ontwikkeling tot goedere en dienste vir die mark.

Kapitaal. Die Suid-Afrikaanse ekonomie as geheel het in die na-oorlogse tydperk ' $n$ neiging tot hoër kapitaalintensiteit getoon. Dit het veral gedurende die sewentigerjare gepaard gegaan met ' $n$ afname in die produktiwiteit van kapitaal. Die gebruik van meer kapitaalintensiewe produksietegnieke, het blykbaar tot die verhoogde kapitaalintensiewe industrieë bygedra. Sekere tegnologiese en bestuursoorwegings, onder andere die land se afhanklikheid van oorsese tegnologie, was ' $n$ verdere bydraende faktor.

Uitvoere. Daar is basies drie kategorieë van uitvoere, nl. roumateriaal, invoervervangers en tegnologiese uitvoere. In die primêre sektor die landbou en mynbou, is landbou minder kapitaalintensief in die sin dat dit meer werksgeleenthede bied per eenheid van investering as bv. die sekondêre sektor (invoervervanging). Die probleem hiermee is egter die relatiewe "elastisiteit" van die primêre sektor - anders gestel, 
daar is nie meer groot potensiaal vir uitbreiding nie, en in die invoervervangingsektor is meer elastisiteit, maar dit is uiters kapitaalintensief. Die uitvoermark het die grootste potensiële elastisiteit, maar dit vereis hoër tegnologie en impliseer ook ' $n$ groter mate van risiko. Nogtans is die voordele van die skep van werkgeleenthede, verdien van buitelandse valuta, ens. só groot dat dit nie geïgnoreer kan word nie.

Gebrek aan Beleid. Die RSA gaan mank aan 'n tegnologiese strategie en -beleid. Hierdie strategie moet gebaseer wees op die skepping van welvaart en 'n hoër lewenskwaliteit. Dit word bereik deur die waarde van manure wat toegevoeg word aan roumateriaal om ' $n$ produk te vervaar$\mathrm{dig}$, te verhoog. So 'n strategie en beleid behoort binne die volgende riglyne daargestel te word, $\mathrm{nl}:$

- Die tegnologiese beleid moet binne die raamwerk van die nasionale ekonomiese beleid geformuleer word tesame met die industriële ontwikkelingstrategie.

- Daar moet op 'n nasionale program vir tegnologiese navorsing en ontwikkeling in lyn met die nasionale doelstellings besluit word.

- Voldoende fondse moet beskikbaar gemaak word om elke fase van die invoer van nuwighede te voorsien en om die kommersiële aanwending van navorsing en ontwikkeling te bevorder. ' $n$ Groter staatsbydrae tot industriële navorsing en ontwikkeling is nodig en die navorsingsbasis moet verbreed word.

- Spesiale maatreëls moet getref word om die tekort aan ingenieurs, wetenskaplikes, bestuurders, tegnoloë en tegnici aan te vul.

- Spesiale aansporingsmaatreëls is noodsaaklik om die betrokkenheid van die private sektor by plaaslike navorsing en ontwikkeling te vermeerder. Hier moet veral klem gelê word op die bewusmaking van die privaatsektor van markte vir hulle huidige of aanverwante produkte. Dan sal hulle gewillig wees om $\mathrm{N} \& \mathrm{O}$ te onderneem om sulke markte te probeer ontgin.

- Verdere ondersoek is nodig vir die vestiging van doeltreffende metode vir die oorplasing van tegnologie (dit is na die finale verbruiker) en leiding met betrekking tot die mees bruikbare tegnologie vir Suid-Afrikaanse omstandighede. (Ons doen tans bitter min aan hierdie uiters belangrike oorweging).

\section{Algemene maatreëls om Tegnologiese Innovasie te bevorder}

Noodsaak. Tegnologiese innovasie verg die volle aanvaarding van die verantwoordelikheid vir vernuwing deur die privaatsektor en die skepping van die regte gesindheid en die nodige infrastruktuur deur die owerheid.

Maatreëls. Die volgende maatreëls word toegepas om tegnologiese innovasie te bevorder:

- Standaarde. Effektiewe prestasiestandaarde van produkte en prosesse word gestel.

- Aansporing. Die koste van tegnologiese vernuwing word verminder deur finansiële en fiskale aansporingsmaatreëls. Bedryfsuitgawes ten opsigte van navorsing, soos alle ander bedryfsuitgawes, word vir belastingdoeleindes afgetrek, maar kapitaaluitgawes is aftrekbaar teen 'n koers van $25 \%$ per jaar tot 'n totaal van $100 \%$ oor vier jaar. Die WNNR oorweeg die instelling van ' $n$ Tegnologiese Ontwikkelingsprogram om die ontwikkeling van vernuwingstegnologie in en deur die fabriekswese te ondersteun deur 'n gedeeltelike bydrae tot die ontwikkelingskoste deur die Departement van Finansies. Hierdie skema sluit enersyds aan by die nywerheidsnavorsingsbeurse van die WNNR wat navorsingsopleiding in nywerheidsnavorsing ondersteun, en andersyds by die gesamentlike ondernemings wat toegespits is op kommersialiseerbare tegnologie.

- Aankope. Staatsaankope van vernuwings en korttermyn-invoerbeskerming van vernuwings, is maatreëls wat toegepas word.

- Beloning. Tegnologiese vernuwing word beloon, byvoorbeeld deur patentwetgewing, voorkeurbehandeling ten opsigte van belastings of vernuwingstoekennings. Sodanige maatreëls is besonder nuttig as dit aan ander aansporingsmaatreëls, byvoorbeeld vir uitvoerbevordering, gekoppel kan word.

- Bestuur. Sakebestuur word verbeter deur steun aan produktiwiteitsorganisasie en subsidiëring van bestuursopleiding. Maatreëls word gemik op die beskikbaarstelling van:

(a) meer bestuurslui en tegnoloë en tegnici, deur steun vir beroepsgerigte onderwys;

(b) beter benutting en verhoging van die mobiliteit van bestuurslui, tegnoloë en tegnici deur meer steun vir beroepsgerigte onderwys, soos aanbeveel deur prof. J.P. de lange, die Kommissie Riekert en Wiehahn en die Naudé-komitee insake die Opleiding en Heropleiding van Blankes, Kleurlinge en Asiërs. 
- Kennis. Steun word verleen aan inrigtings wat tegnologiese kennis voortbring en benut, byvoorbeeld finansiële steun aan universiteite en navorsingsinstansies.

- Oordrag. Maatreëls word gemik op 'n vlotter oordrag van tegnologiese kennis, byvoorbeeld deur die WNNR se wetenskaplike en tegniese inligtingsdienste.

- Infrastruktuur. Die infrastruktuur vir tegnologiese ondernemings word verbeter met insluiting van navorsing en ontwikkeling van die tegnologie oor vervoer, geboue, uitvloeiselbehandeling en vele ander aspekte van nywerheidsinfrastruktuur.

\section{Die RSA se antwoord op boikotte}

Die Verdedigingsnywerheid. "Die wapenproduksie in ons eie land dien as stimulant vir die skepping van nuwe kundigheid en vaardigheid wat ook in ander rigtings ' $\mathrm{n}$ positiewe bydrae tot die algemene vooruitgang maak. Dit skep nuwe bronne van werkverskaffing en welvaart". P.W. Botha (Paratus, Maart 1971, p 69):

\section{- VN Resolusie ten opsigte van Wapenboi-} kotte. Op 7 Aug 1963 het die Verenigde Nasies (VN) Resolusie 181 aangeneem, waardeur lidstate versoek is om hulle van wapenverkope aan die RSA te onthou (Gann, 1978). Dit is egter eers eindelik gedurende Des 1964 deur lande soos die VSA en Brittanje geïmplementeer. ' $n$ Verpligte wapenboikot is deur Resolusie 418 van 1977 deur die Veiligheidsraad ingestel. Hierdie wapenboikotte het vanselfsprekend direkte druk op plaaslike wapenvervaardigingsmoontlikhede geplaas.

- Krygstuigraad. Die RSA Regering het hierop geantwoord deur die aanname van Wet No 87 van 1964, in terme waarvan die Krygstuigraad in die lewe geroep is. Die raad se hooffunksie was die voorsiening van bewapening vir die SAW. Hierdie veranderde houding van die wêreld teenoor die RSA en die VN wapenboikot, het die noodsaaklikheid vir selfvoorsiening in wapens beklemtoon (Conradie, 1982) en in 1966 is prof H.J. Sameuls as die eerste voorsitter van die destydse Krygstuigraad aangestel.

- Krygkor. Gedurende 1968 is die Bewapeningswysigingswet aangeneem en is die Wapenontwikkeling en Vervaardigingskorporasie gestig. Die "eerste" Krygkor is in die lewe geroep om die Raad van die vervaardigingsfunksie te verlos. Gedurende April 1977 is Krygkor en die Krygstuigraad deur een organisasie, die huidige Krygkor, ver- vang. Kmdt Piet Marais is as voorsitter van dié organisasie aangestel.

- Ontwikkeling. Krygkor se groei en ontwikkeling was fenomenaal. Dit is vandag een van die grootste industriële ondernemings in die RSA. Krygkor se bates oorskry R1 200 miljoen en verskaf werk aan sowat 24000 mense van alle rassegroepe.

- Filiale. Krygkor het verskeie geaffilieerde maatskappye. Atlas Vliegtuigkorporasie vervaardig en onderhou vliegtuie, terwyl Telcast spesialiseer in hoë-tegnologiese gietstukke. Infoplan verskaf rekenaardienste en Kentron vervaardig geleide wapenstelsels. Ander filiale konsentreer hoofsaaklik op konvensionele wapens soos bv. Lyttelton Ingenieurswerke (kleingewere en kanonne), Musgrave (kommersiële gewere, haelgewere en handwapens), Naschem (swaarkaliber 'ammunisie en bomme), om slegs 'n paar te noem.

- Resultate. Die uitwerking van die wapenboikot was 'n direkte stukrag vir die ontwikkeling van 'n plaaslike hoë-tegnologiese wapenindustrie wat merkbare suksesse behaal. Die G5 $155 \mathrm{~mm}$ selfaangedrewe howitzerkanon, was byvoorbeeld ' $n$ groot sukses by die internasionale wapenskou gedurende 1982 in Griekeland. Interessant om te weet dat SuidAfrika staan in rangvolgorde nou langs die VSA in die vervaardiging van ammunisie met 143 verskillende tipes ammunisie en meer as 40 tipes dryfladings. Dit word verder bereken dat die RSA nou 95\% selfversorgend is in verdedigingsmateriaal. Hierdie gunstige toestand is bereik ten spyte van die tegnologiese isolasie van die RSA en ' $n$ volgehoue propaganda-aanslag wat die verkryging van sekere materiaal feitlik onmoontlik gemaak het. "South Africa is now the largest arms producer in the southern hemisphere, and the tenth largest in the world". Jonathan Kapstein, (Armed Confrontation Builds in South Africa, in Proceedings of the US Naval Institute, Vol 107, No 12 (Dec 81) p 39).

\section{Spesifieke Kundighede/Bronne}

Binnelands en Buitelands. Wanneer van beskikbare bronne gepraat word, word daar veral op die volgende gelet:

- Energie. Suid-Afrika beskik oor genoegsame energie om aan al ons nywerheidsbehoeftes te voldoen in die vorm van steenkool, uraan, hidro-elektrisiteit (H.F. Verwoerddam) en brandstof uit steenkool (Sasol) ens. 
- Materiale/Grondstowwe. Suid-Afrika beskik oor alle moontlike grondstowwe, hoewel sommiges moeiliker verkrygbaar is as ander.

- Terrein. Suid-Afrika beskik ook oor groot genoeg terreine wat kan dien as oefen/toets terreine. (Lohatla, Elandsfontein, St Lucia, Weskaapland, ens.).

- Mannekrag. Die grootste probleem ten opsigte van bronne is die opleibare mannekrag waaroor Suid-Afrika beskik. Hoewel daar genoeg mense in SA is, is almal nie noodwendig opleibaar nie. Die probleem ontstaan dus om bogenoemde bronne na wense te kan ontwikkel en benut.

- Fondse. Uit ' $n$ totale verkrygings-begroting van R1,6 miljard, word sowat R600 miljoen in die buiteland aan die verkryging van bronne/ tegnologie bestee. Dié R600 miljoen is verspreid oor sowat 10 lande dwarsoor die wêreld. Krygkor filiale lewer produkte ter waarde van ongeveer R400 miljoen van die begroting terwyl die res aan private organisasies betaal word.

- Krygkor Filiale. $\mathrm{Om}$ in die wisselende krygstuigbehoeftes van die RSA te voorsien, maak Krygkor benewens sy filiale ook maksimaal van nywerhede in die private sektor gebruik. Hierdie proses kan nie ongeorganiseerd verloop nie en moet sinvol deur Krygkor benut word. Weens die wisselende krygstuigbehoeftes is die 22 hoofkontrakteurs in die privaatsektor ook uiteenlopend van aard in hulle produkte. Die 11 filiale en hulle produkte/dienste is soos volg:

\section{- Atlas Vliegtuigkorporasie en Telcast.} Hierdie twee firmas is betrokke by vliegtuigvervaardiging, -instandhouding en -diens. Hoë-tegnologiewerk met spesiale delegasies.

- Infloplan. Verskaf rekenaardienste aan die SA Weermag en Krygkor.

- Kentron en Eloptro. Die twee firmas is betrokke by die voorsiening en ontwikkeling van geleide wapens en vervaardiging van optiese toerusting.

- Lyttelton Ingenieurswerke. Vervaardiging en instandhouding van kleingewere en kanonne.

- Musgrave Vervaardigers en Verspreiders. Vervaardigers en bemarking van konvensionele gewere, haelgewere, handwapens en kommersiële ammunisie.

- Naschem. Laai en samestelling van swaarkaliberammunisie en vliegtuigbomme.

- Pretoria Metaalperswerke. Vervaardiging van kleinkaliber-en snelvuurammunisie.

- Somchem. Vervaardiging van dryfmiddels, militêre springstowwe, vuurpylaandryfstelsels en vuurpyle.

- Swartklip Produkte. Vervaardiging van pirotegniese produkte, handgranate en kommersiële ammunisie ens, ens.

Ander organisasies. Deurdat Krygkor se filiale ook in 'n groot mate op die private sektor vir die voorsiening van komponente steun, lewer dié sektor sowat sewentig persent van alle krygstuig wat in die land vervaardig word. Die krygstuignywerheid word as die toonaangewer op tegnologiese gebied aanvaar. Die organisasies wat die ontwikkeling en vervaardiging van die gesofistikeerde uitrusting onderneem, het die land se nywerheid as sodanig van baie groter vaardighede en vermoëns voorsien. Die nywerhede sal, danksy sy uitvoerprogram, binne afsienbare tyd 'n betekenisvolle bydrae tot die land se betalingsbalans lewer.

\section{Voorsiening vir Tegnologiese Ontwikkeling}

\section{Tyds- en Finansiële Implikasies}

Behoeftestelling. Die behoefte aan tyd vir tegnologiese ontwikkeling het beide inherente tydkonstante sowel as ' $n$ veranderlike komponent. Indien die tegnologiese proses as die produksievermoë, tegnologiese vermoë en navorsingsen ontwikkelingsvermoë gesien word, kan tydskonstantes van onderskeidelik drie tot vyf jaar, drie tot tien jaar en vyf tot twintig jaar volgens $d r$. De Wet onderskei word. Die tegnologiese embargo het 'n bepaalde effek op die produksievermoëns sowel as prosestegnologie. Die ontwikkeling van stelsels word gevolglik 'n prioriteit in die RSA se tegnologiese ontwikkeling en dit maak groter aanspraak op veral die skaars hulpbronne van opgeleide mannekrag.

- Begrotingsaksies. Gegewe die feit dat bykans $70 \%$ van alle tegnologiese navorsing en ontwikkeling in die RSA ten behoewe van die verdedigingspoging gedoen word, is dit voor die hand liggend dat dié gedeelte van die verdedigingsbegroting wat aan navorsing en tegnologie toegewys word, van kardinale belang is. Die R125 miljoen wat per jaar aan tegnologiese navorsing en ontwikkeling bestee word, verteenwoordig bykans $8 \%$ van die verkrygings-begroting van die SA Weermag, maar slegs sowat $3 \%$ van die totale verdedigingsbegroting.

- Toekenning van fondse. Aangesien die besteding aan ingevoerde tegnologie in reële 
terme drasties sedert die sestigerjare afgeneem het, is daar ' $n$ groter binnelandse spandering. Die Kleu-verslag meld dat die uitvoermark aan die hoë tegnologie-kant ' $n$ onbeperkte bron van fondse is, wat groter besteding aan navorsing en ontwikkeling moontlik sou maak. Dit is dus belangrik dat plaaslike besteding ook as basis sal dien om uitvoere moontlik te maak. Kleu kan egter met groot vrug gaan kyk na die prysoorlog in die wêreld.

- Evaluasie. Vanweë die toenemende isolasie van die RSA, is die tegnologiese ontwikkeling geneig om ' $n$ eiesoortige rigting in te slaan. gepaard met 'n groter plaaslike besteding aan verdedigingstoerusting beteken dit dat die aantal tegnologiese gebiede waarop plaaslike innovasie benodig word, drasties vermeerder. Dit het tot gevolg dat die komponent van die verdedigingsbegroting wat op $\mathrm{N} \& \mathrm{O}$ spandeer moet word, aansienlik groter sal moet word, sê $8-10 \%$ liewer as die huidige $3 \%$ hierbo genoem. Aangesien ons nog steeds ' $n$ insae het in die doen en late van die Westerse tegnologiese lande, sou ons nie heeltemal die $12-15 \%$ van die VK en VSA hoef te ewenaar nie, omdat ons ietwat op hulle na-yl en dus minder risiko's hoef te loop.

\section{Bedryfsekonomiese Aspekte van Tegnologie-ontwikkeling}

Produksiefunksie. Die produksiefunksie behels die instelling van 'n produksiestelsel en produksiebestuur. Aandag moet dus gegee word aan die verkryging van resultate van die verlangde tipe en kwaliteit ten opsigte van tegniese en inligtingsdienste. Alhoewel die resultate van $\mathrm{N} \& \mathrm{O}$ meesal onderhewig is aan 'n onvoorspelbare komponent, insluitende moontlik onverwagte tekortkominge in die onderliggende wetenskaplike kennis, kan navorsingsbestuur 'n aansienlike bydrae lewer om die skaars hulpbronne (soos mannekrag, fondse en fasiliteite) effektief hiervoor aan te wend.

\footnotetext{
Aankoopfunksie. Die aankoopfunksie verg in hierdie verband dat aandag gegee word aan die hulpbronne wat vir die innovasieproses benodig word. Aangesien die belangrikste inset vir die innovasieproses inligting en beskikbare tegnologiese kundigheid is, vereis dit gespesialiseerde meganismes en kennis om byvoorbeeld die aankoop van geskikte tegnologie vir aanwending en die gepaardgaande probleme soos lisensie-ooreenkomste, te kan hanteer.
}

Bemarking. Die bemarking van tegnologie is ' $n$ verdere belangrike aspek en vereis soortgelyke gespesialiseerde insig in markte, prysvasstellings, die vorm waarin die tegnologie aangebied word (soos byvoorbeeld as patent, kundigheidsooreenkoms, of as ingeboude tegnologie vervat in bepaalde tipes toerusting of grondstowwe wat bemark word) asook die verskaffing van na-verkoop-dienste, en die verkoopsbevordering (byvoorbeeld deur advertensies).

Spesiale Finansiering. Vir die ontwikkeling en benutting van tegnologie is die verkryging en aanwending van fondse van kardinale belang. Vanweë die hoë risiko-element moet dikwels spesiale finansieringsmetodes ontwikkel word. As gevolg van die snelle ontwikkeling van tegnologie, en die risiko van nabootsing of regstreekse onregmatige gebruik van die tegnologie, moet aandag gegee word aan die vinnige verhaling van die groot beleggings wat dikwels hiervoor benodig word.

Administratiewe Funksie. Ten opsigte van die administratiewe funksie moet dus veral aandag gegee word aan sekuriteitsmaatreëls om te verseker dat die tegnologie nie ontydig uitlek nie en aan maatreëls om die ontwikkelaar teen onregmatige gebruik te beskerm.

Eksterne betrekking. Die eksterne betrekkinge funksie behels nie alleen die skepping van die regte beeld nie, maar ook maatreëls om die moontlike, werklike of gewaande nadele van die tegnologie vroegtydig uit te ken en die werklike voordele te beklemtoon.

\section{Tegno-ekonomie as Spesialiteitsgebied}

Innovasieproses. Met die oog daarop om die volle ekonomiese voordeel van tegnologiese innovasie te kan benut, is dit wenslik dat studies van alle aspekte van die innovasieproses uitgevoer word, veral met die oog op die ondersteuning van besluitneming en beleidsformulering in hierdie verband.

Spesialisasie. ' $n$ Spesialiteits-vakgebied, wat in Suid-Afrika bekend staan as tegno-ekonomie, het dus mettertyd ontwikkel om aan hierdie en verwante aspekte aandag te gee. Tegno-ekonomie bestudeer dus die wedersydse interaksie tussen enersyds die ekonomiese aspekte en andersyds die wetenskappe en tegnologie, en gee byvoorbeeld aandag aan:

- studies van $\mathrm{N} \& \mathrm{O}$ 


\section{THE 6B LOCOMOTIVE NO 537 AT FORT KLAPPERKOP MUSEUM}

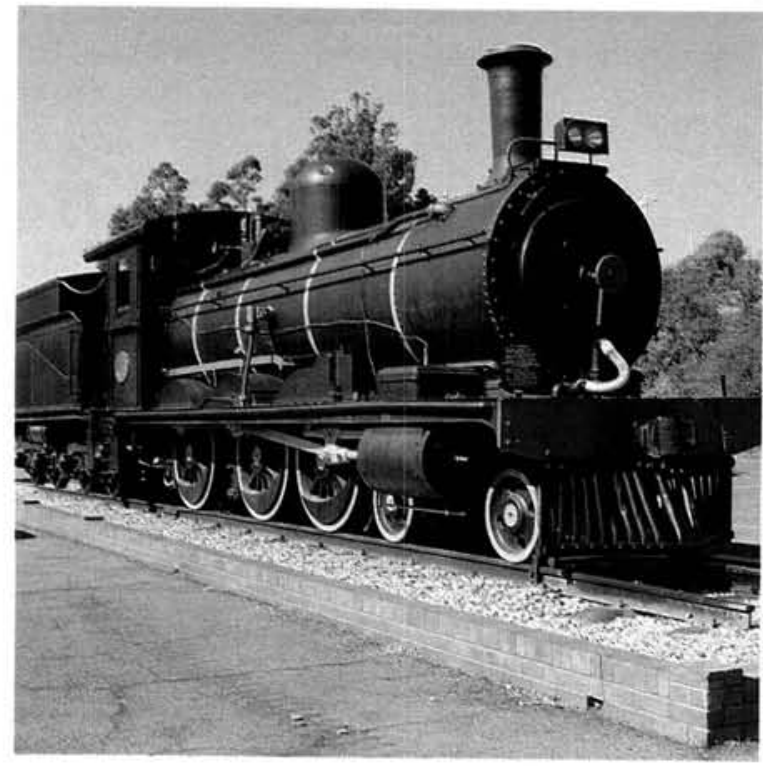

The locomotive on the track constructed for her at Fort Klapperkop Museum

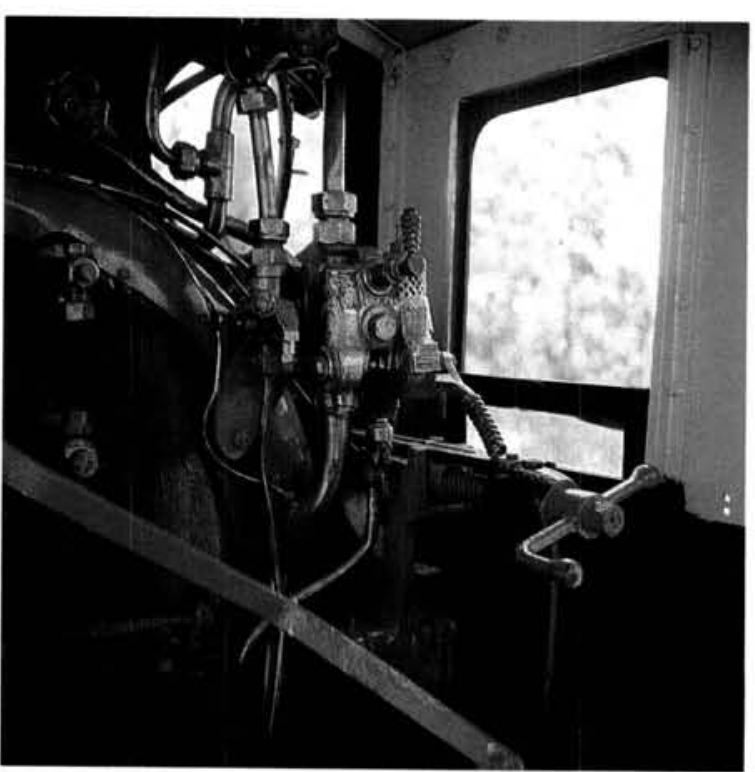

The interior of the cab of the $6 B$ locomotive No 537 at Fort Klapperkop Museum

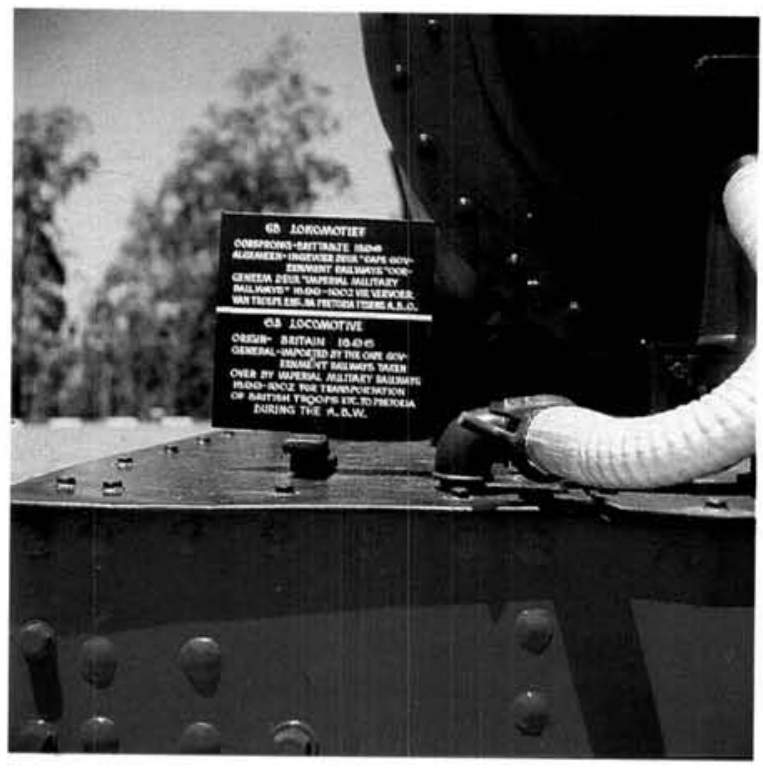

The historic plaque mounted on the locomotive

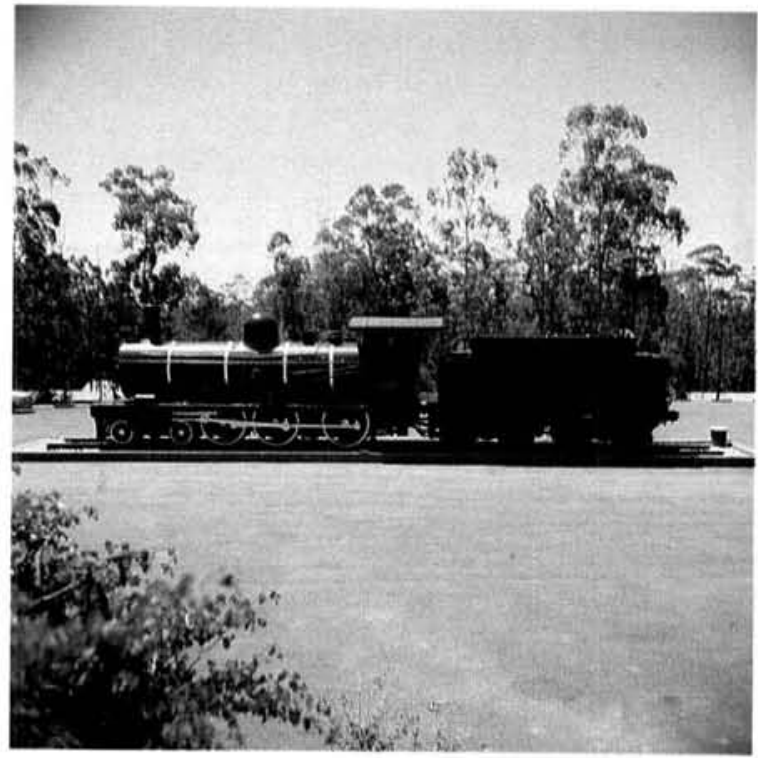

A side-view of locomotive No 537 at Fort Klapperkop Museum 


\section{PETER OGILVIE SE KALENDER}

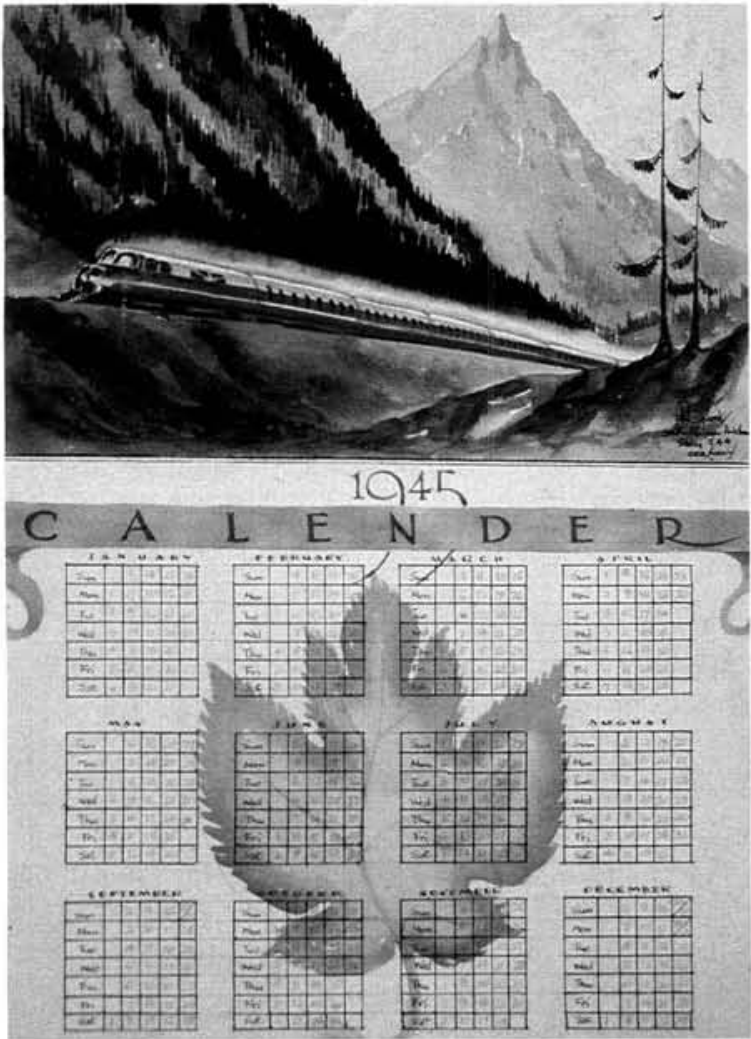

Hierdie is die kalender wat deur Peter Ogilvie geskilder is gedurende die Tweede Wêreldoorlog. Mev. Balland het die kalender aan Suid-Afrika terugbesorg.

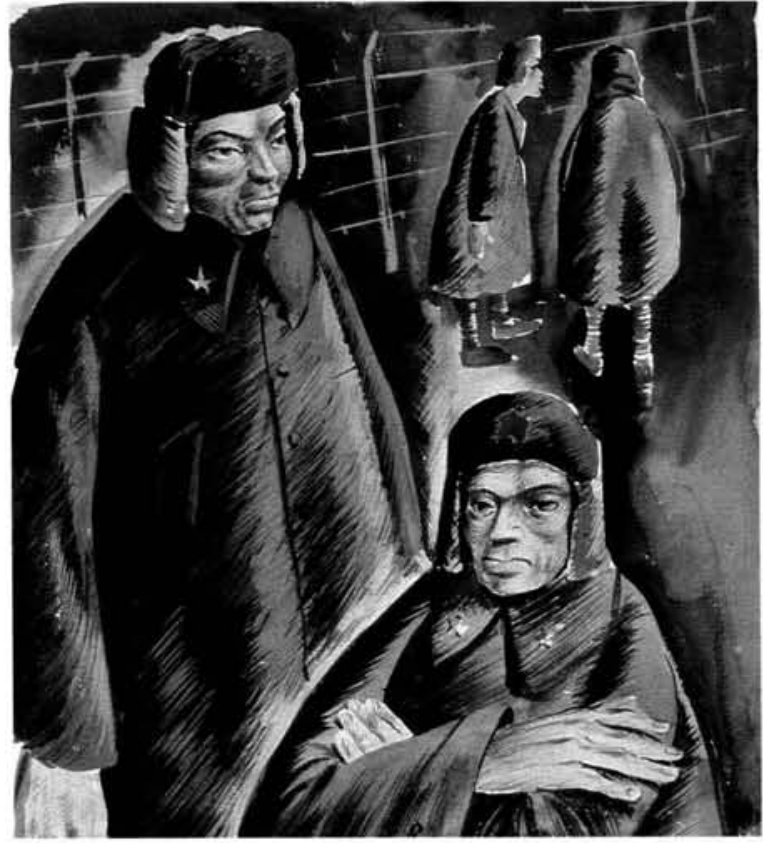

Skets wat deur Peter Ogilvie geskilder is tydens sy krygsgevangenskap.
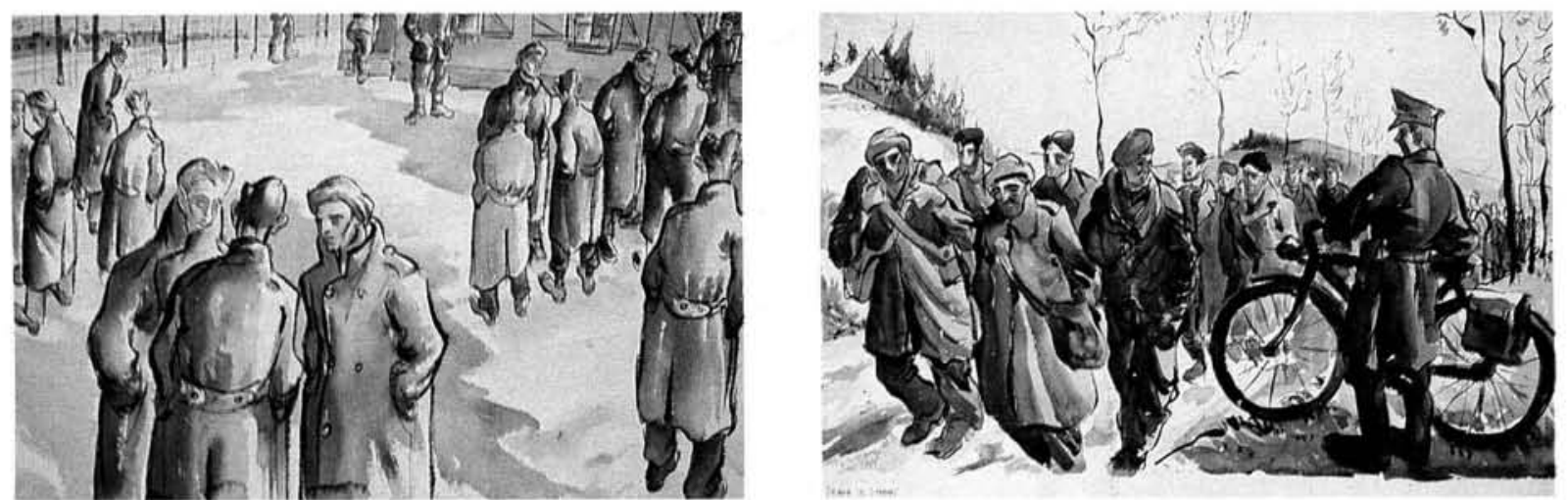

Sketse wat deur Peter Ogilvie geteken is gedurende sy krygsgevangenskap. Dit het saam met sy dagboek op 'n merkwaar̆dige manier behoue gebly. 
- N\&O bestuur en beleid

- uitkenning van ekonomiese geleenthede en bedreigings vir tegnologie

- koste-voordeel en -effektiwiteit van tegnologie

- omgewingsekonomie

- tegnologiese vooruitskatting, en selfs

- meer basiese studies byvoorbeeld oor die aard van tegnologie.

Navorsing. Benewens die WNNR se Groep vir Tegno-ekonomiese Studies gee etlike bedryfsekonome by Suid-Afrikaanse universiteite ook reeds etlike jare aandag aan tegno-ekonomiese navorsing en studies.

\section{Mannekragvoorsiening}

Arbeidsintensiteit. Die uitstaande kenmerk van die innovasieproses is die arbeidsintensiteit daarvan. Aangesien hoë-vlak mannekrag en geskikte werksomstandighede vir byvoorbeeld die skeppende komponent van $\mathrm{N} \& \mathrm{O}$ benodig word, is dit duidelik dat besondere aandag aan die personeelfunksie gegee moet word. Vanweë die kompleksiteit van tegnologie is dit dikwels persoonsgebonde en moet dus spesiale voorsiening gemaak word vir die behoud van kundige persone.

Bestuur. Besondere eise word aan die algemene leidingsfunksie vir die innovasieproses gestel. Die daarstelling van 'n geskikte organisasiestruktuur om enersyds die gespesialiseerde kundighede van bepaalde persone en andersyds die uiteenlopende taakopdragte effektief te akkommodeer, lei dikwels tot die samestelling van projekspanne volgens die matrikstruktuur. Seleksie en opleiding van bestuur om tegnologie-ontwikkelingsprosesse te kan beplan, organiseer, lei en beheer maak die konflikterende matriks-beginsels onnodig. Gedifferensieerde opleiding van bestuurders is noodsaaklik.

Bedryfsekonoom. Die bedryfsekonoom speel ' $n$ baie waardevolle rol in die effektiewe volvoering van die innovasieproses, beide as direkte deelnemer aan sekere van die stappe in die proses en deur die verskillende funksies betrokke by die proses, te ondersteun en te bestudeer.

Mannekragopleiding. Die opleiding van werknemers is ' $n$ belangrike aspek van "hoë tegnologie-maatskappye" se personeelbeleid. Deskundige vaardighede is ' $n$ belangrike komponent van wapenproduksie. Om daardie bekwaam- hede te ontwikkel is dit vir byvoorbeeld Krygkor nodig om op die hoogte van internasionale tegnologiese ontwikkeling te bly. Krygkor het ' $n$ baie wye reeks opleidingskemas beskikbaar. Binne ' $n$ enkele jaar sal byvoorbeeld 5000 werknemers opleiding van een of ander aard ondergaan.

Vaardighede. Afrika ly soos meeste ander streke van die wêreld ook oor die algemeen aan 'n tekort aan kritieke vaardighede wat in die industrialiseringsproses nodig is. Dat lande in Afrika van hierdie tekorte bewus is, is duidelik uit hulle wetgewing en verskillende reëlings met oorsese vennote om die ontwikkeling van plaaslike mannekrag te verseker. Terwyl beleide en wette van verskillende grade van doeltreffendheid bestaan en selfs al is sommige institute geskep, ontduik doeltreffende implementering steeds die nasionale beplanners. Daar word gesê dat die redes vir mislukking die volgende insluit:

- Die onbekwaamheid om nasionale beleid te implementeer deur diegene wat moet verseker dat die plaaslike personeel progressief opgelei word om buitelandse werknemers te vervang.

- Die praktyk van buitelandse beleggers om voorwaardes van indiensneming af te dwing wat nie deur die beskikbare personeel uitgevoer kan word nie.

- Die onwilligheid van buitelandse beleggers om doeltreffende oorplasing van tegnologie te laat geskied.

- Die swak onderhandelingsposisie van lande wat tegnologie invoer.

- Die begrip van watter tegnologie benodig word en die prosesse waardeur dit gevestig word, bestaan nie in die land waarheen dit ingevoer word nie.

Tekort aan Mannekrag. Daar bestaan geen twyfel dat dit buitelandse beleggers loon om die gedagte van ' $n$ tekort aan mannekrag te propageer nie, omdat hulle daardeur makliker in staat is om kritieke bestuurs- en tegniese poste vir buitelandse werknemers te reserveer, waardeur die ontwikkeling van plaaslike tegnologiese bekwaamheid gefrustreer word. Die probleem is veelvoudig want in baie gevalle bestaan daar nie ' $n$ inventaris van plaaslike beskikbare mannekrag of oor hoe dit benut word nie. Gevolglik is daar gevalle waar hierdie tekort meer denkbeeldig as werklik is.

Mannekragvereistes. (vir navorsing en ontwikkeling). Daar bestaan ' $n$ behoefte om ' $n$ behoor- 
like distribusie van mannekrag, beide in getalle en kwaliteit, tussen die verskillende aktiwiteite dwarsdeur die innovasieketting te bewerkstellig. Soos langs die innovasieketting voortbeweeg word, is daar ' $n$ vinnig stygende koste aan die een kant en 'n progressiewe verandering in die getal en kwaliteit van die professionele personeel op die besluitnemingsvlakke. Beide hierdie gevolge verteenwoordig hindernisse teen suksesvolle benutting van die oorspronklike uitvinding en kan lei tot nadelige tyd-vertragings, onvoldoende werkverrigting (van die produk of fabriek) of selfs om die projek te laat vaar. Nie alleen is hierdie gevolge verontrustend op sigself nie, maar kan ook twyfel in die gedagtes van diegene laat ontstaan wat fondse moet voorsien om hierdie duur nuwighede te steun, wanneer hulle genooi word om in die volgende een te belê. Hierdie ontevredenheid kan kumulatief wees en kan lei tot ' $n$ element van sinisme wanneer nuwe geleenthede gebied word om te belê in wat ' $n$ baie goeie projek kan wees.

Mannekragmotivering. Daar bestaan geen bloudruk of kitsoplossing vir sukses nie. Sukses kan alleen bereik word met deurlopende harde werk, duidelike doelwitte, goeie motivering en 'n aangename omgewing.

Doelwitte. Duidelike doelwitte vir tegnologiese ontwikkeling bly ' $n$ voorvereiste vir sukses. Daar is egter talle voorbeelde van ontwikkelinge wat wel plaasgevind het as gevolg van een of ander briljante inspirasie of ' $n$ toevallige ontdekking tydens ' $n$ navorsingsprogram. Gelukkig is daar baie bewyse wat daarop dui dat innovasie plaasvind vanweë 'n spesifieke behoefte. Goeie voorbeelde hiervan is die dramatiese ontwikkelinge gedurende wêreld-oorloë en andere soos byvoorbeeld kernkrag, ruimte-navorsing ens.

Betrokkenheid van Topbestuur. Topbestuur se betrokkenheid beteken om te weet en te aanvaar dat groei en vooruitgang alleenlik deur tegnologiese innovasie na vore kom.

Begroting. Suksesvolle ontwikkeling kan ook net materialiseer met die nodige befondsing beskikbaar. Ongelukkig is daar ' $n$ verskil tussen Navorsing en Ontwikkelingspersoneel en Topbestuur se persepsie van befondsing van ontwikkelinge ("'n Topbestuur wat 'n korttermyn winsbejag nastreef, vreet sy saadaartappels op").

Kreatiewe Omgewing. Seker een van die belangrikste aspekte van suksesvolle innovasie is 'n kreatiewe omgewing. Sonder dit, kan geen geld in die wêreld sukses koop nie. Daar bestaan nie ' $n$ eenvoudige formule vir sukses nie. Dit kan egter die produk wees van vele faktore soos byvoorbeeld bestuurstyl, spangees, kommunikasie tussen bestuur en staflede en tussen die navorser en verskeie motiveerder.

Faktore. Werksatisfaksie, erkenning en vergoeding dra by tot die motivering van die personeel ten einde sukses te demonstreer in terme van tegnologiese innovasie.

Verantwoordelikheid. Die wetenskaplike word met alle moontlike geredskap toegerus soos befondsing, verantwoordelikheid en gesag om die navorsing te doen. Die verantwoordelikheid is dikwels die belangrikste motiveerder.

\section{Verbetering en Bevordering van Industriële Infrastrukture}

Beleggings. Met die daarstelling van verdedigingstegnologie, het Suid-Afrika groot beleggings gemaak om die Suid-Afrikaanse industriële infrastrukture te verbeter en uit te bou. Onlangse voorbeelde dui daarop dat die Staat R1 892 miljoen die afgelope paar jaar belê het in die staatsbeheerde Yster en Staal Korporasie van Suid-Afrika (YSKOR), wat tans 5,8 miljoen ton staal per jaar produseer. Die Hoëveld Staal en Vanadium Korporasie het R250 miljoen sedert 1968 belê en het die wêreld se grootste leweransier van vanadium geword (word gebruik vir gevorderde allooie). In 1978 het die Regering R19,7 miljoen aan tegnologiese oordrag bestee. In 1979 het Suid-Afrikaanse wetenskaplikes ook die gebruik van alkohol en waterstof as plaasvervangers vir brandstof begin verken as alternatiewe brandstowwe om die Sasolaanleg aan te vul, wat olie uit steenkool produseer.

Platina. In 1980 het die SA Regering die vestiging van 'n presisie gietery aangekondig nodig vir lugruimwerk - by Alberton, en 'n uitbreiding van die skema by die Impala Platina Myn naby Rustenburg. Dit het die Impala Platina Myn naby Rustenburg die tweede grootste verskaffer van platina buitekant die Warskou-verdrag gemaak.

Produksiebasis. In 1981 is die ontwikkeling van 'n produksiebasis vir vlekvrye staal en ander gespesialiseerde metale aangekondig. Hierdie metale word ook vir vliegtuigontwikkeling en -vervaardiging benodig. 


\section{TEGNOLOGIESE VOORUITGANG IN SUID-AFRIKA}
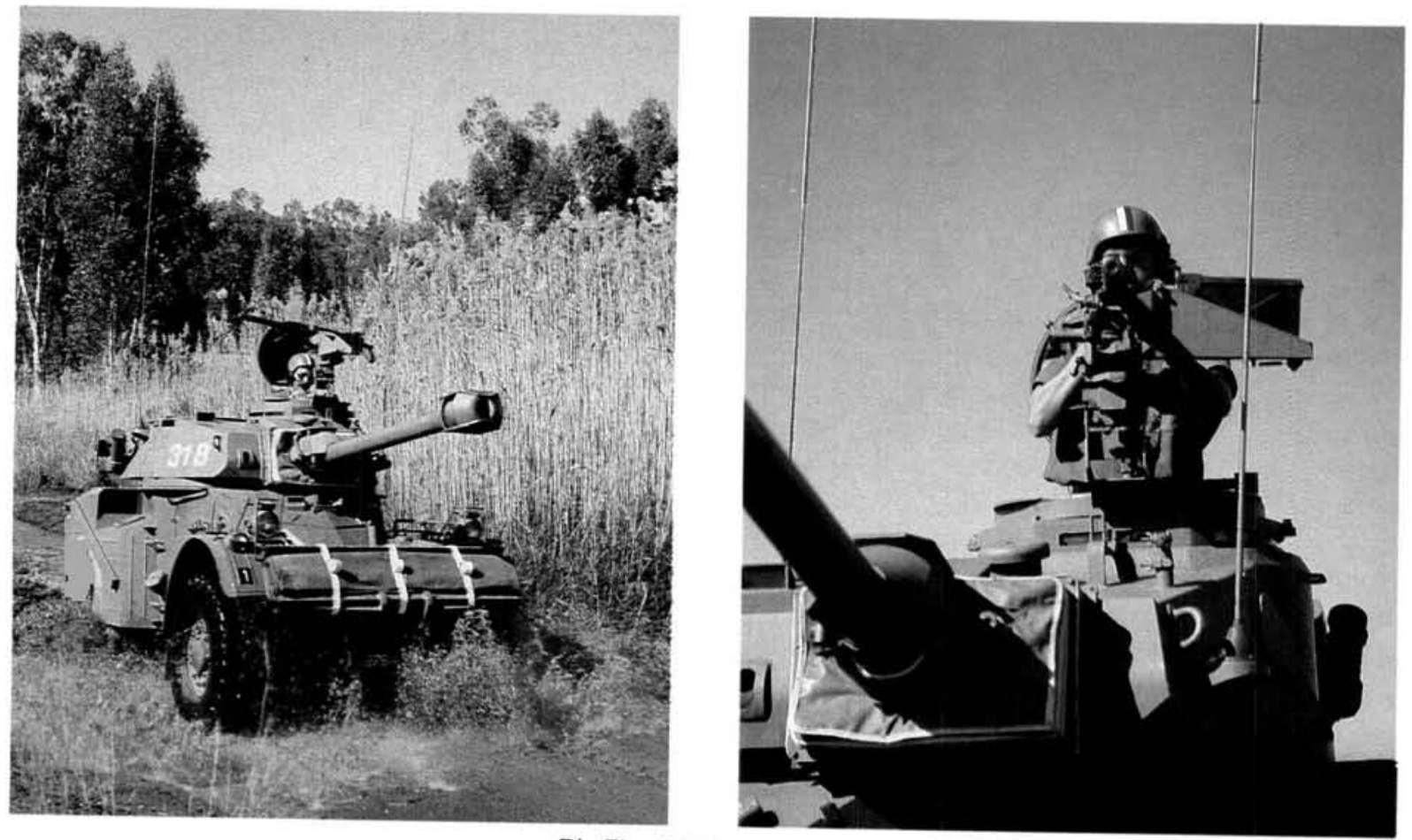

Die Eland 90 Pantserkar

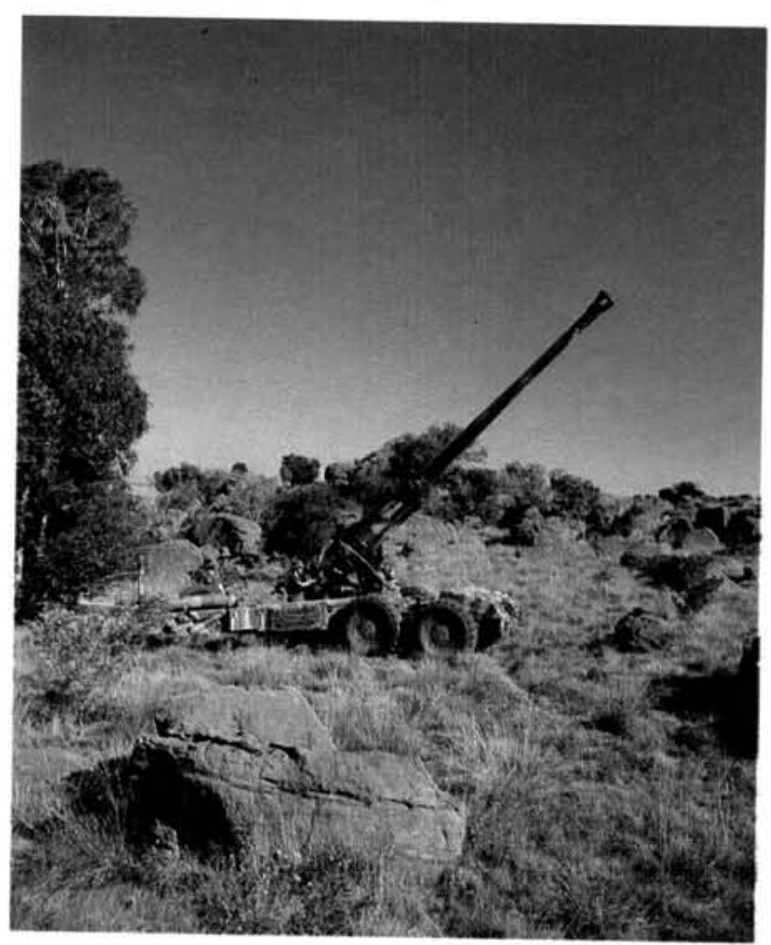

Die G5 155mm Artilleriestuk

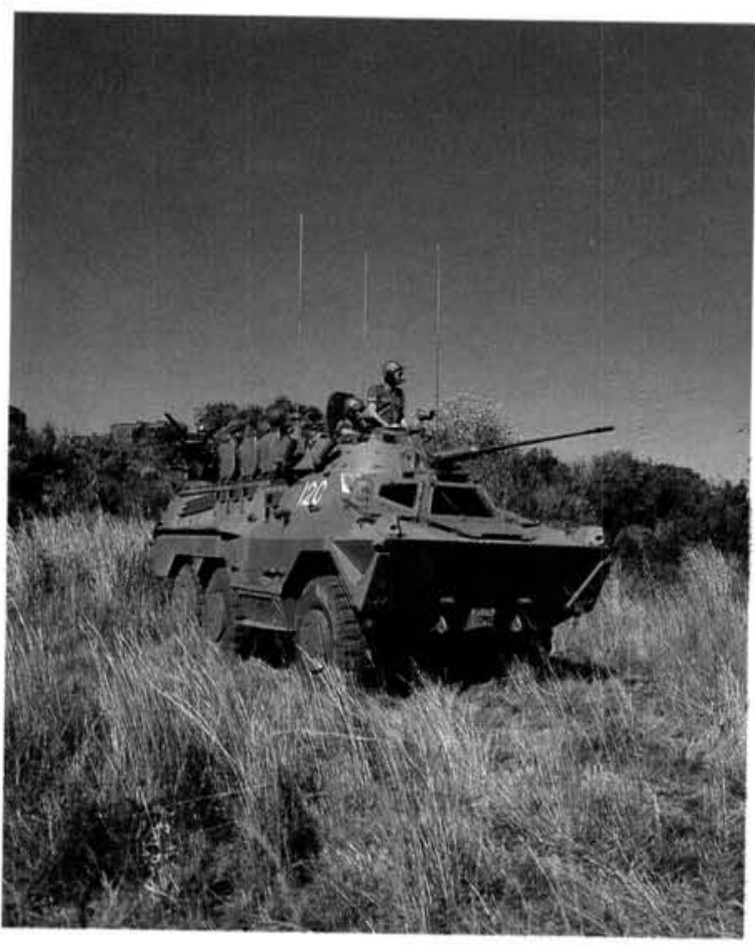

Die Ratel Infanteriegevegsvoertuig met 20mm kanon 


\section{OORLOGSKUNS}

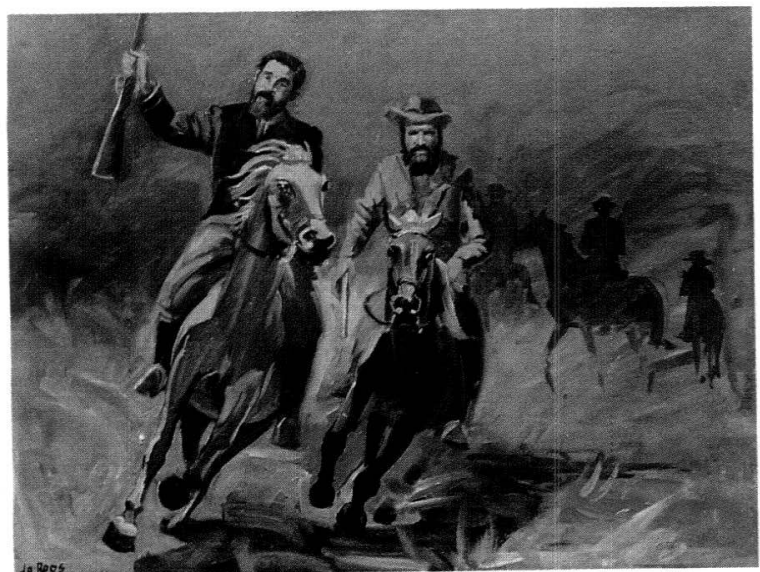

Die Anglo-boereoorlog. Skildery deur Joe Roos

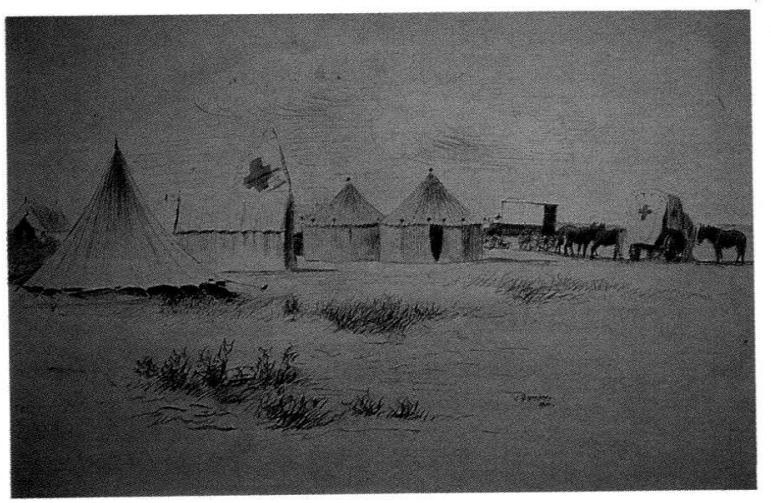

Pretoria Ambulans te Modderrivier November 1899 tot Februarie 1900.

Skildery deur Frans Oerder

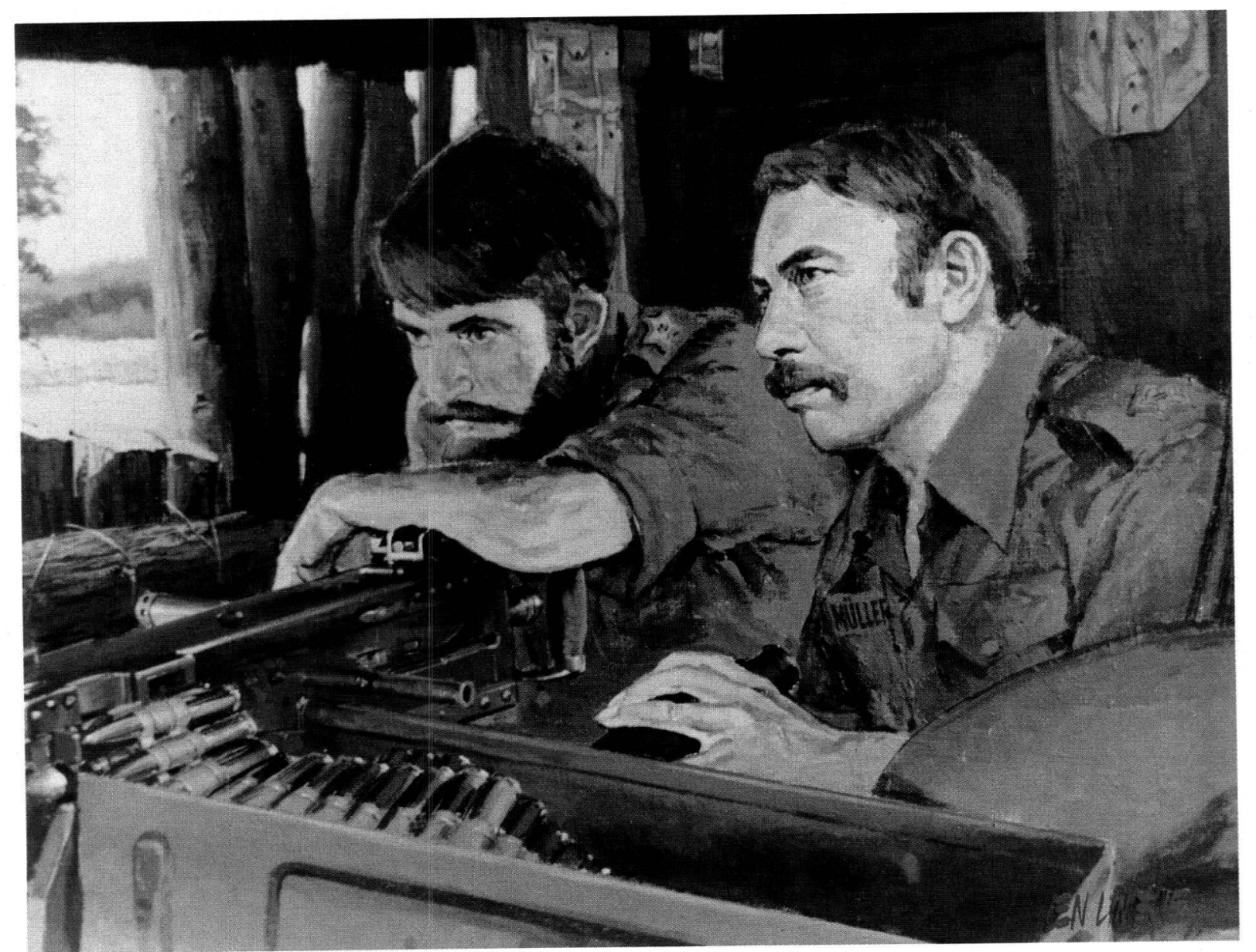

Bravo Bunker. 'n Masjiengeweerbunker geskilder deur Len Lindeque 


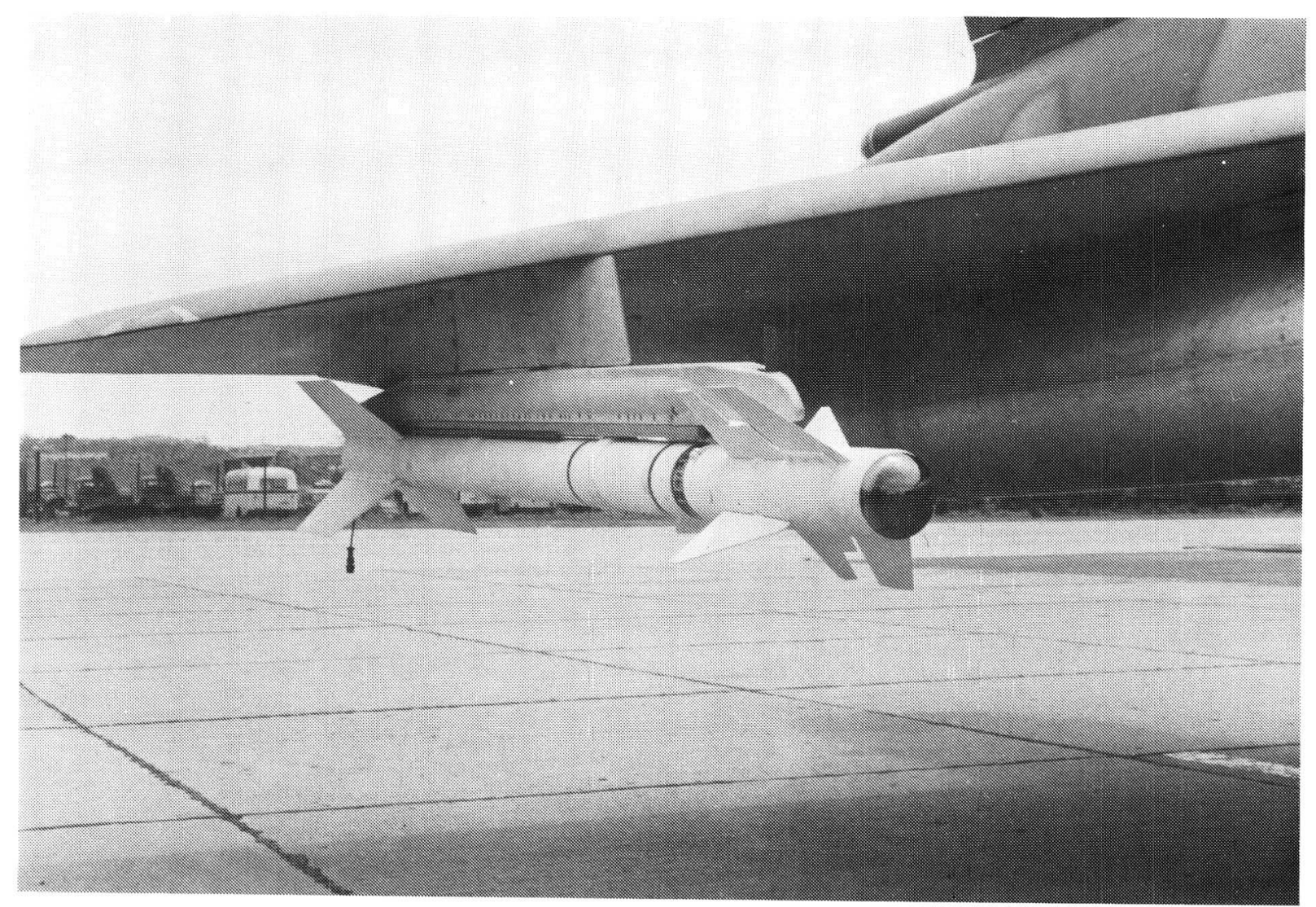

Die Suid-Afrikaansevervaardigde Kukri/V3 lug-tot-lug misstel.

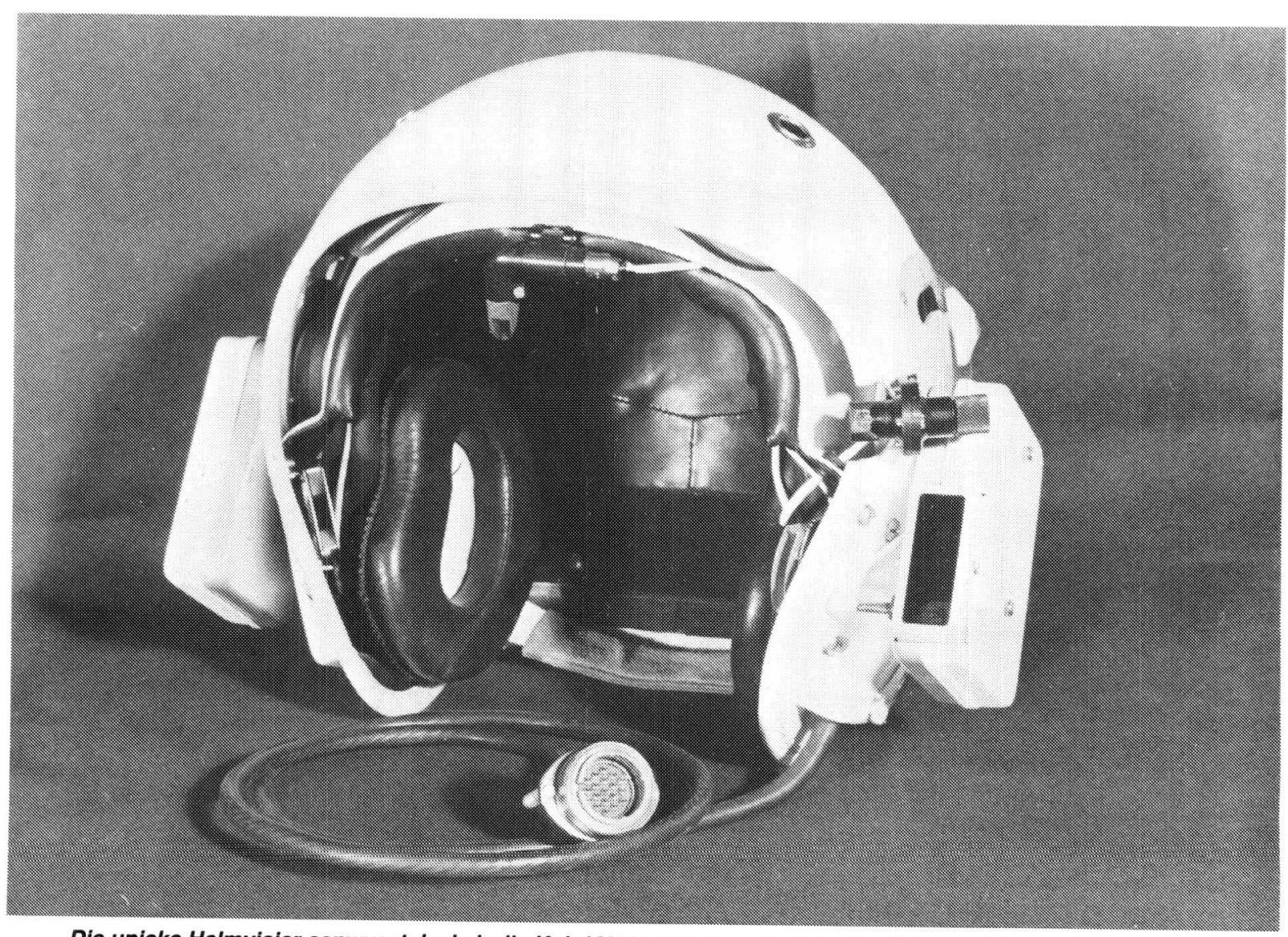

Die unieke Helmvisier aanwysstelsel vir die Kukri/V3 lug-tot-lug missiel wat ook 'n produk van Suid-Afrika is. 


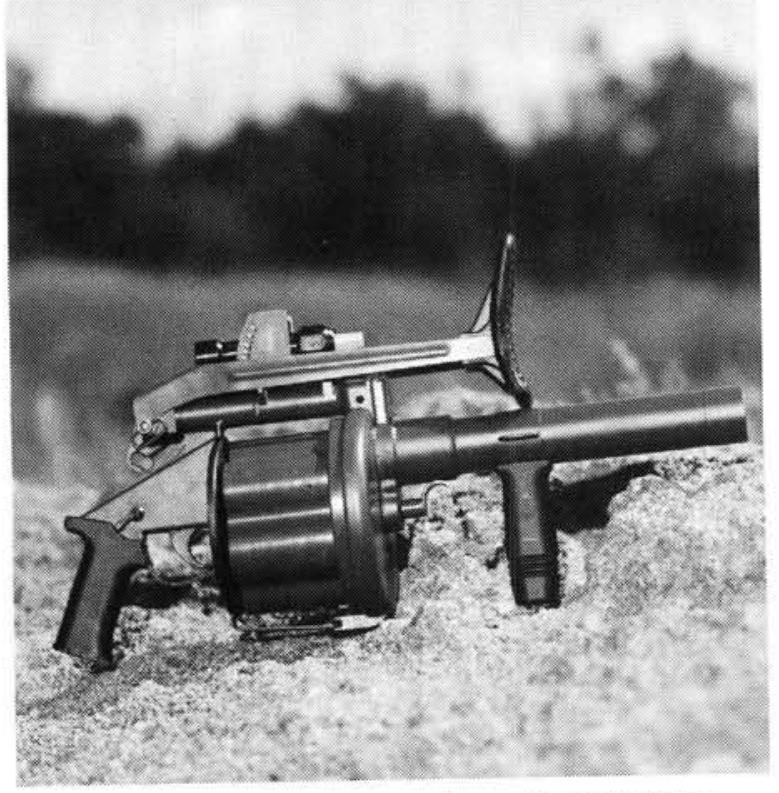

Die 6-Skoot Granaatlanseerder wat in Suid-Afrika ontwikkel is.

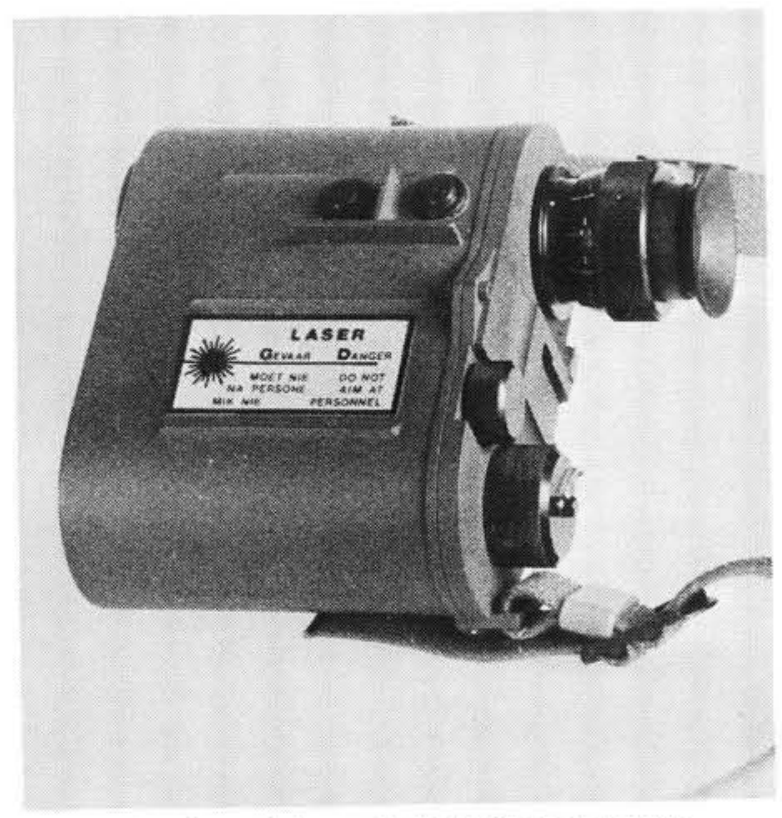

Nog 'n produk van Suid-Afrika is die Laser Afstandmeter.

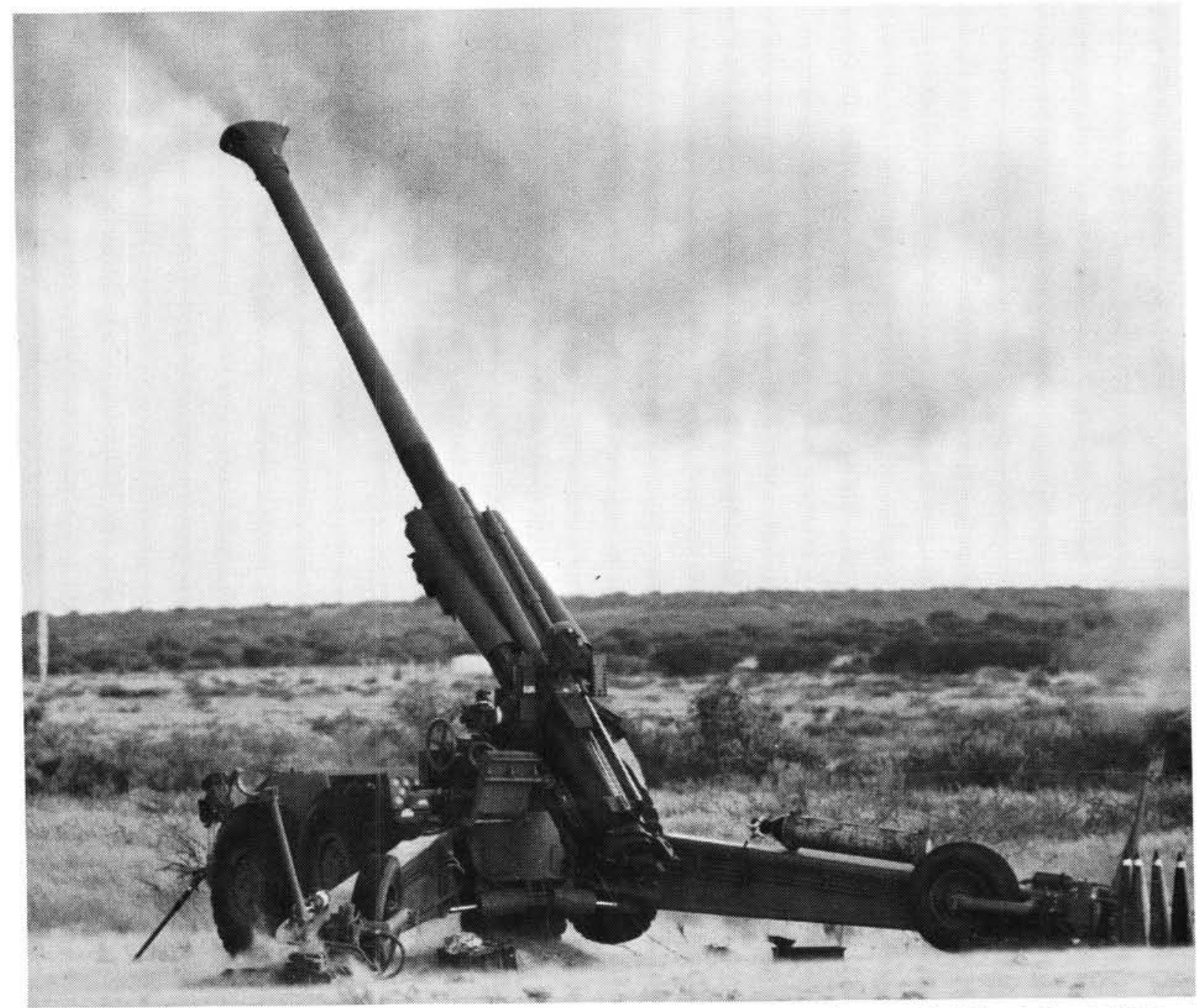

Die G5 Howitzerkanon is deur Suid-Afrika op selfaangedrewe wiele gemonteer (genoem die G6) wat elie wêreld se grootste en swaarste aangedrewe gevegsvoertuig is. 
Krygstuig. 'n Bewys van die groeiende gesofistikeerdheid van die Suid-Afrikaanse Krygstuigindustrie, is die daarstelling van plaaslike vervaardigde of gemodifiseerde krygstuig in vergelyking met wat elders in die wêreld voorkom. Die Sandock-Austral Maatskappy wat die Eland pantserkar gebou het (dit was gewild en baie suksesvol om Angolese en Kubaanse tenks uit te skakel) het sy ervaring met die Eland gebruik om 'n seswielaangedrewe infanterie gevegsvoertuig nl. die Ratel, te produseer. Krygkor het die G5 howitzer-kanon geneem en op selfaangedrewe wiele gemonteer, genoem die "G6". Dit weeg \pm 36 ton, is $10 \mathrm{~m}$ lank, en 3,25 m breed en die wêreld se grootste, swaarste aangedrewe gevegsvoertuig. Die onlangs ontwikkelde Kukri lug-tot-lug missiel, toon beslis ooreenkomste met die Franse "Matra Magic 550", maar is gemodifiseer met ' $n$ helm-gemonteerde teiken aanwys-stelsel, wat uniek in die wêreld is. "The net result of this is, that South Africa has by far the most advanced, balanced, and powerful military capability on the African continent ... more effective striking power than all of black African combined" (Andrew J. Pierre, The Global Politics of Arms Sales (Princeton, N.J. Princeton University Press, 1982), p 267). Dit is nie net ' $n$ funksie van die toerusting nie, maar ook die gehalte mannekrag wat ons het.

\section{ALGEMENE TEGNOLOGIESE BEPERKINGS}

\section{(a) Probleme}

Tegnologie in die nywerheidsontwikkeling in Suid-Afrika ondervind die volgende probleme:

- Beleid. Die formulering van die nywerheidsen tegnologiese beleid, is nog nie behoorlik gestruktureer en gekoördineer nie.

- Besteding. Die besteding van die owerheid en die privaatsektor aan navorsing en ontwikkeling is klein in vergelyking met dié van baie ander lande en is nie wyd oor die nywerheid versprei nie.

- Kundiges. Daar bestaan 'n tekort aan kundiges in sakebestuur, die wetenskap en die tegnologie vir die skepping, aanpassing en gebruik van die geskikte tegnologie.

- Beplanning. Daar bestaan ' $n$ ernstige gebrek aan gekoördineerde en geïntegreerde beplanning op alle vlakke in ons land.

- Vaardigheid. Genoegsame tegnologiese vaardighede het in die RSA ontbreek toe die propaganda-oorlog (teen die RSA) op tegnologiese isolasie afgestuur het.
- Kontinuïteit. Daar is ' $n$ gebrek aan begrip oor die kontinuïteit tussen opleiding, navorsing, tegnologie en nywerheid.

- Mannekrag. Genoegsame mannekrag uit alle lae van die bevolking het ontbreek toe daar 'n krisis in wapenvoorsiening in die RSA ontstaan het. Vandag nog is daar steeds ' $n$ tekort aan geskikte personeel.

- Infrastrukture. Voldoende infrastruktuur kan alleen ontwikkel word deur vooruitbeplanning van bates maar ook van laste (tekorte).

- Tegniese Afsondering. Die RSA se isolasie het tot gevolg dat selfs buitelandse besoeke en -opleiding moeiliker word.

- Ingevoerde Tegnologie. Suid-Afrika is in 'n groot mate afhanklik van ingevoerde tegnologie. In dié verband bestaan ' $n$ behoefte aan ' $n$ skeppende aanpassing van die buitelandse tegnologie by Suid-Afrikaanse omstandighede en die verwerwing van praktiese ervaring met sodanige tegnologie.

- Beleggings. Dit bly steeds 'n moeilike saak om te besluit of groot kapitale beleggings gemaak moet word vir tegnologie-ontwikkeling, en of daar eerder gesmokkel moet word. Die antwoord sou sekerlik 'n goeie balans wees.

- Navorsing en Ontwikkeling. Navorsing en ontwikkeling is in Suid-Afrika nog on ' $n$ groot mate ' $n$ owerheidsfunksie. Dit is nodig dat private nyweraars meer betrokke sal raak by navorsing en dat die navorsers hulle meer rig tot die eise van die mark en ons unieke werksituasie.

\section{(b) Effektiewe Tussengangers}

Tegnologie-oordrag is een van die moeilikste nywerheidsoptredes. Voorwaardes vir suksesvolle tegnologie-oordrag is:

- Skenker/ontvanger pariteit.

- Die mees direkte kontak tussen skenker en ontvanger (gewoonlik is mensemobiliteit 'n voorvereiste).

- Ná hierdie twee voorwaardes kom sulke aspekte soos dokumentasierypheid, ens.

- Transformasiehulp. Daar bestaan in SuidAfrika 'n behoefte aan "transformasie"-hulp om tegnologiese ontwikkelings te kommersialiseer, dit wil sê om te skep in goedere en dienste vir die mark. Daar bestaan ' $n$ tekort aan risiko-kapitaal vir hierdie doel en 'n gebrek aan samewerking tussen nyweraars en die Suid-Afrikaanse Ontwikkelingskorporasie vir Uitvindings, wat help om tegnologiese deurbrake te kommersialiseer. 
- Mark. Die beperkte Suid-Afrikaanse mark bemoeilik die toepassing van sekere tegnieke. Die meeste Suid-Afrikaanse nywerheidsondernemings is ook betreklik klein. Daarenteen het die ondervinding deur die wêreld getoon dat meer as die helfte van verskillende vorme van tegnologiese vernuwing afkomstig is van individue en klein ondernemings wat meesal 'n tekort het aan lantermynkapitaal, oor ontoereikende bestuurskundigheid beskik en ' $n$ behoefte het aan finansiële- en regsleiding en steun by die afset van hul produkte.

\section{Foute gemaak}

Foute. Ondergenoemde "foute en flaters" het ten doel om identifikasie vir regstelling daar te stel.

- Isolasie. Tegnologiese vaardigheid in die RSA het ' $n$ agterstand wat duidelik aan die lig gebring is met die toenemende propagandaaanslag in die vorm van tegnologiese en wapenisolasie. Ons afhanklikheid van die buiteland moet deeglik bestuur word. Ons het vinnig ingehaal maar is nou egter weer besig om agter te raak.

- Beplanning. ' $n$ Kernagtige tekort aan vooruitbeplanning of beplanning van toekomstige (of verwagte) tekorte het die RSA in die sestiger jare gekenmerk. Aangesien propaganda-metodes al meer op die weerhouding van tegnologie gerig gaan word, sal dit raadsaam wees om vir toekomstige tekorte te beplan, soos met die 1977-78 beplanning van mannekragbehoeftes gedoen is ( $\mathrm{vgl}$ tabel gelewer deur kantoor van die Eerste Minister).

- Anderskleuriges. Die fout wat gemaak is deurdat nie genoeg anderskleuriges en mense uit alle bevolkingsgroepe en lae van die algemene bevolking opgelei is nie, word kennelik weerspieël in die afwesigheid van hierdie mense in die Navorsings- en Ontwikkelingsveld. Die RGN en WNNR (om maar twee instansies te noem) het wel van anderskleuriges gebruik gemaak, maar dan bloot as veldwerkers by opnames. Werklike opleiding van N\&O beamptes het nie plaasgevind nie. Daarom is daar in 1984 geen of weinig balans tussen mannekragaanvraag en -voorsiening.

- Koördinering. Effektiewe beroepsvoorligting, gepaard met stimulasie, uitbreiding en promosie van navorsing, het nie gekoördineerd plaasgevind nie. Dit is te veel as ' $n$ slim luukse bygevoeg nadat in die "basiese" opvoedingsbehoeftes voorsien was en dan slegs op ad hoc manier.
- Salarisse. Wetenskaplik gebaseerde salarisstrukture wanneer loopbaanvooruitsigte gebied word, het mank gegaan aan realistiese weerspieëling van mannekragvereistes en -behoeftes. Die prys wat daarvoor betaal is, al was dit tot beskerming van die openbare en privaatsektor gedoen, (as dit sou wees) was te hoog.

- Marknavorsing.Die privaatsektor is nie betyds en genoegsaam gewerf vir navorsingsen ontwikkelingsbehoeftes nie, met ander woorde 'n meer markgerigte N\&O word benodig.

- Proses-tegnologie. Krygkor het op SAW aandrang groot industriële kapasiteite (proses-tegnologie) teen groot kapitaal opgerig. Hierdie vermoëns is inderhaas met buitelandse kundigheid (lisensies) tot stand gebring. Die tegnologie is verouderd, die kapasiteite veel groter as ons behoeftes en die produkte is nie bemarkbaar nie. Die probleem sentreer rondom 'n gebrekkige markpeiling en beplanning.

- Tegnoloë/Tegnologie. Dit was 'n fout om tegnoloë so lank in te voer uit die buiteland. Die probleem met ingevoerde tegnoloë is, soos met ingevoerde tegnologie, die vervanging daarvan, enersyds, en die inbou daarvan in die ekonomiese strukture andersyds. Daarby kom dat die word deur die opstelling van inventarisse van beskikbare plaaslike tegnoloë en gebeurlikheidsbeplanning as aanduiding van wat verwag kan word en van hoe verwagte poste gevul kan word. Daar is egter steeds ' $n$ groot behoefte aan kritiese kundighede vanuit die buiteland om hier te vestig.

\section{DIE PAD VORENTOE: AANBEVELINGS}

Voorstelle. Ten einde tegnologiese-innovasie op 'n gesonde voet te plaas binne die RSA, behoort die volgende aanbevelings die tegnologie-pad te verbeter en uit te bou:

- Propaganda. Die privaatsektor sal in die RSA in baie hoër intensiteit gemotiveer moet word om die propaganda-aanslag te vertolk en saam te werk aan ' $n$ stelsel-(proses)-matige aanpak van navorsing en ontwikkeling ('n Nasionale program vir $\mathrm{N} \& \mathrm{O}$ word benodig).

- Beleid. Tegnologiese beleid moet in die RSA in noue aansluiting met, en binne die raamwerk van, nasionale ekonomiese en politieke beleid gedoen word en sodoende 'n nasionale industriële ontwikkelingstrategie ontwerp word. 
- Fondse. Genoegsame fondse moet beskikbaar gestel word om elke fase van tegnologiese innovasie te beplan en te bekostig om sodoende die kommersiële toepassing van $\mathrm{N} \& O$ te laat slaag.

- Navorsing. Alhoewel die WNNR en die RSA se universiteite ' $n$ neiging tot "ivoortoring" navorsing het, sal die universiteite en WNNR moet nywerheidskant toe groei en die nywerhede N\&O kant toe.

- Beplanning. Gekoördineerde en geïntegreerde beplanning op alle vlakke het noodsaaklik geword.

- Isolasie. Die wapenboikot het die ontwikkeling van selfvoorsiening in die vervaardiging van wapens vir die RSA genoodsaak. Hierdie selfvoorsiening het ewewydig met die propaganda-aanslag teen die RSA, wat op isolasie sou afstuur, ontwikkel. Tegnologiese isolasie moet met oorleg bestuur en beheer word.

- Reklame. Die manier waarop die RSA die wa deur die drif getrek het en tegnologies selfvoorsienend geword het, het aan hom 'n magtige propagandawapen verskaf, asook die propagandamateriaal waarmee Krygkor en andere op internasionale uitstallings die aandag van die internasionale media kan trek. 'n Breë reklame en opvoedingsprogram moet van stapel gestuur word.

- Opleiding. Innovasie op breë tegnologiese gebied kan alleen geskied op die basis van geslaagde navorsing- en ontwikkelingsprogramme en infrastruktuur. Dit noodsaak 'n omvattende in-diepte strategie wat die herskryf van opvoedings- en opleidingsbeleid verg. Hierby moet gevoeg word die ontwikkeling van bestuursvernuf.

- Materiaal. Die RSA moet voortdurend op die uitkyk wees vir nuwe kanale vir materiaal wat in die ontwikkeling van sy wapenstelsels gebruik kan word. Die ontwikkeling van hipertegnologiese wapenindustrie het alreeds verskeie aansporings vir die Republiek se ekonomie gelewer, waaronder die voorsiening van meer as 24000 werksgeleenthede en het ook die privaatsektor tot ' $n$ groot mate in sy ondernemings betrek. Die verhoogde verdedigingsbesteding het die vrye ekonomiese besteding tot 'n hoë mate gestimuleer. As bloot in verhouding gekyk word na die besteding op die verkrygings-begroting tussen die Krygkor filiale en die privaatsektor (R400 miljoen teenoor R600 miljoen) dan beteken dit sowat 40000 werksgeleenthede in die privaatsektor wat by voorsiening aan verdediging betrokke is.
- Bemarking. Die kundigheid sowel as die uitvoer van hiper-tegnologiese wapensisteme het die ekonomie van hoog nodige inkomste voorsien. Op grond hiervan kan verwag word dat 'n meer gesofistikeerde en aggressiewe bemarking in die buiteland ' $n$ prioriteit sal word. Ofskoon dit so is, is daar terselfdertyd die beperkings wat uitgewys is as tekorte in mannekrag, vaardighede en geldelike bronne. Dit kan die tegnologiese innovasie as plusfaktor van die mislukte propagandaveldtog (teen die RSA) in gevaar stel.

Steunfunksies. Naas tegnologie moet die volgende steunfunksies ontwikkel word ten einde die tegnologie sinvol te ondersteun, $\mathrm{nl}$ :

- bestuursfunksies

- mannekragontwikkeling en -opleiding

- operasionele navorsingsfunksies

- kwaliteitsversekeringsaspekte

- sisteem-ingenieurswese (om sisteem te verseker en los pakkie-navorsing te verhoed)

- professionele betroubaarheidsprogramme

- professionele evaluasie-programme

- professionele logistieke beplanning

Privaatsektor. Groter aansporingsmaatreëls moet daargestel word ten einde privaatsektor betrokkenheid aan te moedig.

Vergoeding. Noodsaaklike aanpassings van opvoeding-en vergoedingstelsels het dringend noodsaaklik geword.

Selektiwiteit. Deeglike beplanning dui enersyds daarop dat die RSA op sekere terreine onafhanklik moet wees van die buiteland en andersins op sekere ander terreine nie noodwendig nie, veral waar dié tegnologie bekostig kan word.

Belegging. Daar moet ' $n$ fyn balans in ons beleggings tussen tegnologie-ontwikkeling en die smokkel van tegnologie wees.

Ooreenkomste. Meer ooreenkomste met uitgeweke-/uitgeworpe lande ("Pariahstates") moet aangegaan word sodat hulle doelwitte ook ons s'n sal wees. Dit sal beteken dat hulle 'n produk ontwikkel wat ook ons benodig - en omgekeerd. Dit kan tyd- en geldbesparend wees.

Magsbasis. Tegnologie neem elke dag in belangrikheid toe en het 'n direkte invloed op die staatkundige-, ekonomiese-, maatskaplike- en veiligheidskomponente van die magsbasis. Dit 
het derhalwe noodsaaklik geword dat tegnologie voortaan as ' $n$ vyfde komponent van ons magsbasis beskou en waardeer word.

\section{SLOTSOM}

Koördinering. Dit het noodsaaklik geword dat tegnologie binne die RSA verder uitgebou en gesinkroniseer word met die daarstelling van ' $n$ koördineringsliggaam. Só 'n liggaam sal alle organisasies en instansies se navorsing koördineer veral ten opsigte van prioriteite en poging. Duplisering en oorvleueling sal verhoed word en eenheid van poging en rigting sal duur tegnologiese innovasie bevorder en verseker.

* Brig F.S. (Shylock) Mulder. Hierdie artikel is 'n verwerking van sy stafgeskrif tydens die Gesamentlike Stafkursus No. 14/84 te SA Verdedigingskollege en word gepubliseer met die vergunning van die SA Verdedigingskollege.

\section{Bronne}

1. Conradie, D. Militaria, 1312,1983

2. Departement of Constitutional Development and Planning. Science Policy and Development Programme for the RSA. Pretoria: October 1982.

3. de Wet, G. Manager: Research and Development: ARMSCOR. Personal Communication. 18 September 1984.

4. de Hemptinne, Y. Military Research and Its Impact on World Peace, Pugwash, op cit, pp 390.

5. Gann, L.H. South Africa and the US Arms Embargo. South Africa International, $1978,8(3)$.

6. Hofmeyr, H.P. (1982) Technology: An investment for Tomorrow. Finance and Trade Review 15 (1): 24-37. June 1982, Pretoria.

7. Haberer, Joseph. Science and Technology Policy.

8. Kleu, A. Nywerheidstrategieë vir die RSA. Staatsdrukker, 1983.

9. Krygkor. Dit is Krygkor. Pretoria, 1984.

10. Leontief, W.W. (1982). The Distribution of Work and Income. Scientific American 247 (3): 152-164, September 1982.

11. Maddock, I. Research organisations and their Contributions. Conference on Innovation in Industry, Pretoria, February 1981.

12. Sadie, J.L. Labour Force 2000, HSRC, RSA 2000, 1981, 3 (2).

13. US Department of Commerce, 1967. Technological Innovation: its Environment and Management. 